\title{
A OPOSIÇAO "DOMINADOR/DOMINADO": ELEMENTO ESTRUTURAL NA OBRA DE RULFO *
}

\author{
Myrna Solotorevsky **
}

\section{Introdução}

Uma leitura adequada da obra de Rulfo revela constantes em virtude das quais nos parece lícito postular que as narrativas de El llano en llamas 1 c. o romance Pedro Páramo 2 são configuradoras de uma isotopía. 3

- Trabalho patrocinado por The Israel Commission for Basic Research. Traduçāo do espanhol (revista pelo prof. Miguel Wouk) por Cecília Teixeira de Oliveira Zokner, da Universidade Federal do Paraná.

- Myrna Solotorevsky e Doutora em. Filosofia (menção Literatura Geral) pela Universidade do Chile (1969) com it tese Nueve pocmas de Poeta en Nueva York. De 1961 a 1970 leclonou Literatura Espanhola Moderna e Literatura Espanhola Medieval no Departamento de Espanhol da Universidade do Chile. A partir de 1971 é Leitora no Departamento de Estudios Españoles y Latinoamericanos de la Universidade Hebrea de Jerusalém. Publicou: Análisis intrínsico comparativo de Camino de Perfección de Pio Baroja y La Voluntad de Azorín. Boletín de Filologia de la Universtad de Chile, tomo XV, p. 111-164, 1963. Análisis de la Careta de Elena Quiroba. Anales de la Universidad de Chile, Año CXXIV. Ene-mar. 1966, n. ${ }^{\circ} 137$, p. 221-228. Análisis de Bienvenido Bob de Onetti. La palabra y el hombre. Revista de la Universidad de Veracruz. Ene-mar. 1973, n. 5, p. 3-10. Vida y muerte en García Lorca y Pablo Neruda. Scripta Hierosolitana. Volumen XXVI, Jerusalem, 1974, p. 226-257. La ironia en Hay un dia feliz de Nicanor Parra. Explicación de Textos Literarios. V. III-2 .1974-1975 (California State University, Sacramento), p. 119-126. Desgaste, lucha y derrota en algunas obras de Onetti. Cuadernos Hispanoamericanos. Madrid. Oct.-dic. 1974, n.. 292-294, p. 209-235.

1 RULFo, Juan. El llano en llamas. México, Fondo de Cultura Economica. 1965. $143 \mathrm{p}$

2 RULFo Juan. Pedro Páramo. México, Fondo de Cultura Economica, 1955. 129 p.

3 Ainda que näo seja este um estudo especificamente semântico, será importante utilizar certos conceitos empregados por Greimas os quais daräo consistência a nossa análise. Referimo-nos a "isotopia" e "actantes". Entendemos por isotopia um plano de significaçāo homogênes (Veja-se a respeito GREIMAS, A. J. In:Semantica. La isotopia del discurso. In: - Semantica estructural, Madrid, Gredos, 1973. p. 103-55). Consideramos os "actantes" como classes de atores cuja esfera de atividade nāo varia de um relato para outro; cada ator: a1, a2, a3, se manifestaria no discurso como expressão ocurrencial de um línico actante Al definido pela mesma esfera de atividade. (Veja-se GREIMAS, A. J. Reflexiones acerca de los modelos actanciales. In: - Semantica estructural, p. 263-93). Do modelo actancial mitico oferecido por Greimas apenas ocupamos as denominaçōes "adjuvante", "oponente" que o referido autor estima como circunstantes. (Greimas, p. 275). "Dominador", "dominado" corresponderiam a um nivel mais superficial que aquele dos actantes assinalados por Greimas podendo ser considerados como papéis actancials. "Veja-se GREIMAS, A. J. Les actants les acteurs et les figures. In:- Essais de sémiotique poétique. Paris, Larousse, 1972).

Letros, Curitiba (25) : $251-292$, jul. 1976 
O objetivo deste trabalho é o estudo de uma dessas constantes. Trata-se da oposiçāo actancial que nos permitirá estudar a conformaçāo, o sentido ou funçāo e o desenvolvimento da oposiçāo "dominador/dominado", além das fronteiras correspondentes a cada narrativa, sem que isto signifique um desconhecimento da autonomia que, sob outra perspectiva, reconhecemos em cada texto individual. 4

Partindo dessa suposição, propomo-nos:

a) demonstrar a cxistência desta oposiçāo em cada um dos textos selecionados;

b) descrever a atualizaçāo da oposição em cada narrativa, o que permitirá a captação de constantes e variantes - confirmadoras também da isotopia, e, com isto, o estudo da configuraçāo dinâmica da oposição no corpus selecionado;

da oposiçāo actancial "dominador-dominado" que parece cumprir, nos diferentes textos, uma função ideológica.

A mencionada oposição é estruturalmente relevante $\mathrm{cm}$ vários contos de El llano en llamas e em Pedro Páramo, se bem que no romance, devido a determinados fatores, esta oposição é menos evidente. (Destacamos entre tais fatores: complexidade do assunto, maior amplitude do mundo configurado, modelo de um âmbito surrealista).

Considerar a obra de Rulfo como uma isotopia, é uma suposição básica

c) mostrar que por meio da conformação desta oposição, se observa uma norma ideológica implicita que denuncia e condena a idcologia imperante no mundo apresentado.

Cada análise finalizará com dois pontos que denominamos: 1) "Definição e configuração da relação actancial" e 2) "Função da narrativa em relação à oposição que nos ocupa". A definição pretenderá captar, na sua essência, a indole da relaçāo; a configuraçāo corresponderá à perspectiva da

4 A critica existente advertiu, noutro tipo de aproximaçāo. o caráter unitário da obra de Rulfo baseando-se na presença de constantes. Graciela B. Coulson assinala: "Tanto em EI llano en llamas como em Pedro Páramo as conotaçōes culturais sāo abundantes no plano conceptual (relações com a Biblia, com Faulkner, com Shakespeare, etc.); a linguagem, no entanto, evita qualquer afetaçäo e toda alusāo literária explícita, dando uma enganosa impressão de primitivismo". (COULSON, G. B. Observaciones sobre la visión del mundo en los cuentos de Juan Rulfo. In: GIACOMAN Helmy F. Homenaje a Juan Rulfo. Madrid, Anaya/Las Américas, 1974. p. 331). Samuel O'Neill se refere à repetiçāo de frases, idéias e situaçōes em El llano en llamas e em menor grau em Pedro Páramo para enfatizar a lentidāo monótona, o afastamento e a suspensāo do tempo é a repetição de frases, idéias e situaçōes (O'NEILL, Samuel. Pedro Páramo. In: GIACOMAN, p. 311). Carlos Blanco Aguinaga chega a afirmar: "Todos os rastos essenciais da visăo do mundo e do estilo dos contos de Rulfo reaparecem em Pedro Páramo, seu primeiro e excelente romance: o mesmo fatalismo diante do brutal e aparentemente mecánico acontecer exterior; a mesma atitude ensimesmáda e lacónica dos personagens, a mesma objetividade narrativa. Somente que, agora, tudo isto como veremos, levado ao máximo extremo de aparente irrealidade e subjetivismo". (BLANCO AGUINAGA, Carlos. Realidad y estilo de Juan Rulfo. In: SOMMERS J. La narrativa de Juan Rulfo; interpretaciones críticas. Mexico, SEP/Setentas, 1974, p. 109). 
qqual se plasma a oposição. Em segundo lugar, consideraremos a contribuiçāo que a narrativa - cada uma delas - supōe na configuração dinâmica à oposição.

Apresentaremos em cada caso a definição da relação actancial mediante uma fórmula cujos termos corresponderão ao seguinte repertório de possibilidades:

domínio: a

acatamento: $b$

consciência (do dominado a respeito de sua situação como tal): $\mathrm{c}$ inconsciência (do dominado a respeito de sua situaçāo como tal): c manifestação discursiva do dominado atualizando sua consciência: d

O corpus sobre o qual trabalharemos incluirá o romance Pedro Páramo c: os seguintes contos de El llano en llamas:

a) Macário, b) Nos han dado la tierra, c) La cuesta de las comadres, d) El hombre, e) En la madrugada. 5

\section{El llano en llamas}

2.1 Macario: narrativa inaugural de El llano en llamas.

2.1.1 Atualizaçāo da oposiçāo actancial

Dominador: a madrinha

Dominado $\left\{\begin{array}{l}\text { Macario..........adjuvante de Felipa } \\ \text { (narrador homodicgético ator protagônico) } \\ \text { Felipa...........adjuvante de Macario }\end{array}\right.$

O esquema realizado nos apresenta o actante "dominador" atualizado por um ator individual: a madrinha, e o actante "dominado" articulado em dois atores: Macario (narrador homodiegético) 6 e o ator protagônico) e Felipa. Os atores "dominados" são adjuvantes um com respeito ao outro.

2.1.2. Os atores dominados

2.1.2.1. Macario

2.1.2.1.1. Macario é um personagem psicótico, traço que se revela quando a narrativa já está adiantada. As primeiras frases do texto tendem a criar no leitor virtual, a falsa imagem de um Macario criança, imagem que se descanece gradualmente. Um traço predominante neste ator psicótico é a sua "redução" pessoal, que se manifesta em diversos planos:

5 Respeitamos a ordem de precedência dos relatos selecionados em El llano en llamas por considerá-la não causal.

6 Genette denomina "relato homodiegético" aquele cujo narrador pertence a diegesis que narra (é personagem) e "relato heterociegético" aquele cujo narrador nāo pertence à diegesis. (GENETTE, Gerard. Figures III, Paris, Seuil, 1972. p. 281). Consideramos mais claro e preciso adjudicar os qualificativos "homodiegético" e "heterodiegético" ao narrador e por extensāo, ao destinatário. 
a) o elementar de seu discurso: "Agora já faz muito tempo que não me dá para chupar dessas saliências que tem onde temos somente as costelas". 7

b) Inconsciência a respeito de suas açōes, as quais se vincula a falibilidade de sua memória: "Um dia inventaram que eu andava enforcando alguém; que lhe apcrtei o pescoço a uma senhora assim, por nada. Eu não me lembro". 8

c) Ausência de cordura na maneira de atuar: bate na própria cabeça durante horas porque deseja escutar o ruido do tambor.

d) Suas relaçōes com os outros atores: absoluto acatamento à madrinha. Dependência de Felipa e respeito por ela (ela tira os demônios de seu corpo, confessando-se por ele)

- Vítima dos outros: "Eu por isto. para que não me apedrejem, vivo sempre metido em casa". 9

A narraçāo a cargo de um narrador homodiegético, permite a apresentação desta redução completa e imediatamente.

2.1.2.1.2. As condiçōes materiais em que vive Macario são deploráveis: em seu quarto há percevejos, baratas, escorpiōes: "Deito de costas c ao sentir alguma barata caminhar com suas patas ásperas sobre o meu pescoço dou-lhe um manotaço e a esmago". 10

2.1.2.2. Felipa

2.1.2.2.1. Aparece configurada, na perspectiva de Macario, em confronto com o ator dominador; aparecendo claramente a preferencia de Macario por Felipa.

a) Macario descreve os olhos de ambas e, em virtude das associaçōes, deixará perceber a malignidade dos olhos da madrinha: "Os sapos são negros. Também os olhos de minha madrinha são negros". "Felipa é quem diz que não se deve comer sapos, Felipa tem os olhos verdes como os olhos dos gatos". "As rãs são inteiramente verdes, menos na barriga... as rãs são boas para se comer". 11

7 "Ahora ya hace tiempo que no me da a chupar de los bultos esos que ella tiene donde tenemos solamente las costilles" p. 10 .

B "Un día inventaron que yo andaba ahorcando a alguien; que les apreté el pescuezo a una señora nada más por nomás. Yo no me acuerdo" $p$. 10.

9 "Yo por eso, para que no me apedreen, me vivo siempre metido en mi casa" p. 12 .

10 "Me acuesto sobre mis costales, y en cuanto siento alguna cucaracha camurur con sus patas rasposas por mi pescuezo le doy un manotazo y la aplasto" p. 10.

11 "Los sapos son negros. También los ojos de mi madrina son negros". "Felipa es la que dice que es malo comer sapos, Felipa tiene ios ojos verdes como los ojos de los gatos". "Las ranas son verdes de todo a todo, menos en la panza... las ranas son buenas para hacer de comer con ellas" p. 10.

Octavio Armand destaca adequadamente estas associaçōes: "Ranas verdes / ojos verdes de Felipa; comer ranas / Felipa cocinera, nodriza”. (Räs verdes / olhos verdes de Felipa; comer räs / Felipa cozinheiro, ama").

p. 342 .

ARMAND, Octavio. Sobre las comparaciones de Juan Rulfo. In GLACOMAN, 
b) Macario dirá claramente: "Eu gosto mais da Felipa que da minha madrinha". 12

c) A madrinha provoca temores. Felipa espanta os medos de Macario.

2.1.2.2.2. Suas funções são: fazer compras, preparar a comida para os três. São tarefas leves em comparação com as de Macario, segundo ele mesmo constata: "Não faz outra coisa desde que a conheço. O de levar os traste sou eu que faço. $O$ de acarrear lenha para fazer o fogo também sou eu que faço". 13

2.1.2.3. Os atores dominados como adjuvantes

2.1.2.3.1. Felipa como adjuvante de Macario

As funções que Felipa cumpre como adjuvante de Macario, correspondem aos planos seguintes:

a) Ambito nutricio:

- Dá de comer a Macario (p. 9)

- As vezes, quando não tem vontade de comer, dá a Macario seu próprio montinho de comida (p. 10)

- Dá de beber a Macario o leite de seus peitos e o excita sexualmente: “... e o leite de Felipa era desse sabor, só que eu gostava mais porque ao mesmo tempo que me dava de beber, $\mathrm{Fe}$ lipa me fazia cócegas por todas as partes". 14

E importante assinalar que um dos problemas fundamentais de Macario é a fome: "Por isto é que eu gosto de Felipa, porque sempre tenho fome, nunca estou cheio, nem se como a comida dela. Ainda que digam que a gente fica cheio comendo. Eu sei muito bem que não fico cheio mesmo que coma tudo o que me dêem". 15 Porque acredito que no dia em que deixe de comer vou morrer c então irei, com toda a certeza, direitinho para o inferno".16

b) Apaziguamento de temores:

- Através da sensualidade "Mas, vem Felipa e espanta os meus medos. Me faz cócegas com as mãos como ela sabe fazer, me tira o medo que tenho de morrer". 17

12 "Yo quiero más a Felipa que a mi medrina" p. 9

13 "No hace otra cosa desde que yo la conozco. Lo de lavar los trastes a mi me toca. Lo de acarrear la leña para prender el fogón también a mi me toca" $\mathrm{p}$. 9

14 "... y la leche de Felipa era de ese sabor, sólo que a mi me gustaba más porque al mismo tiempo que me pasaba los tragos, Felipa me hacía cosquillas por todas partes" p. 11

15 "Por eso quiero yo a Felipa, porque siempre tengo hambre, 8 no me lleno nunca, ni aun comiendome la comida de ella. Aunque digan que uno se llena comiendo. Yo sé bien que no me lleno por más que como todo lo que me den" p. 10

16 "Porque yo creo que el día en que deje de comer me voy a morir y entonces me iré con toda seguridad al infierno" p. 14

17 "Pero viene Felipa y me espanta mis miedos. Me hace cosquillas con sus manos como ella sabe hecerlo y me ataja el miedo que tengo de morirme" p. 11 
- Por meio da religião: vai confessar-se por ele. "Por isso se confessa todos os dias. Não porque seja má, mas porque estou cheio de demônios por dentro e ela tem que me tirar estes demônios do corpo confessando-se por mim". 18

2.1.2.3.2. Macario como adjuvante de Felipa.

Quando um escorpiăo pica Felipa em uma nádega, Macario a fricciona com saliva, reza por ela e, ao ver que o remédio não a alivia, a ajuda a chorar: "[...] ajudei-a a chorar com meus olhos tudo o que eu pude". 19

Destacamos a importância que a sensualidade adquire na relaçāo entre Macario e Felipa: na ajuda de Felipa se combinam a função nutrícia e apaziguante com a sensualidade, e esta última aparece destacada na ajuda que Macario dá a Felipa.

2.1.3. O ator dominador

2.1.3.1. A vontade da madrinha determina o ato de enunciação (o monólogo de Macario: Macario fala para não dormir e assim cumprir a ordem de matar as rãs, que perturbariam o sono da madrinha (p. 14)

2.1.3.2. Exerce absoluta autoridade: "é minha madrinha quem manda fazer as coisas". $20 \mathrm{E}$ a madrinha que impõe as tarefas a Felipa e a Macario (a este corresponde matar as rãs, lavar os trastes, juntar lenha para acender o fogo, varrer a rua, dar de comer aos porcos).

2.1.3.3. Possui poder econômico: "Mas é minha madrinha que tira dinheiro de sua bolsa..." 21

2.1.3.4. E a distribuidora dos bens: "Depois é minha madrinha quem nos reparte a comida. Depois de comer, faz com suas mãos dois montinhos, um para Felipa e outro para mim". 22

E sugestivo que Macario descreva esta atividade como um trabalho que a madrinha realiza.

2.1.3.5. e) e depositária do conhecimento e da verdade. "Ela sabe... ela sabe... ela sabe... (p. 14)" "Mas com tudo isto, é minha madrinha quem diz o que eu faço e ela nunca anda com mentiras". 23

2.1.3.6. f) A cor de seus olhos (pretos) associado a cor dos sapos, considerados malignos.

18 "Por eso se confiesa todos los dias. No porque ella sea mala, sino porque yc estoy repleto por dentro de demonios y tiene que sacarme esos chamucos del cuerpo confesándose por mi" p. 11

19 “... la ayudé a llorar con mis ojos todo lo que pude ... p. 13

20 "... es mi madrina la que me manda hacer las cosas" p. 9

21 "Pero es mi madrina la que saca el dinero de su bolsa" p. 9

22 "... luego es mi madrina la que nos reparte la comida. Después de comer, ella hace con sus manos dos montoncitos, uno para Felipa y otro para mi" p. 9

23 "Ella sabe... ella sabe... ella sabe..." ( $p$. 14) "Pero a todo esto, es mi madrina la que dice lo que yo hago y ella nunda anda con mentiras" p. 10 
2.1.4. - A religião como instrumento de domínio.

A religião assim como está plasmada no relato é uma força que contribui para avassalar o ator dominado:

2.1.4.1. a) $\mathrm{Na}$ igreja, Macario deve permanecer com as mãos amarradas.

2.1.4.2. b) Teme o inferno acreditando que seu corpo está repleto de demônios.

2.1.4.3. c) A condenação ao inferno parece inevitável: a madrinha ameaça Macario com o inferno, como castigo por golpear-se a cabeça; paradoxalmente. Macario realiza tal açāo para "salvarse del infierno" (provocar um ruido semelhante ao daquele cujo estrépito chega até a igreja, atẹnuando as condenaçōes do padre).

2.1.4.4. d) Observe-se que o termo "madrinha" tem implicações religiosas e se aplica a algućm que protege o outro (mulher que tem, apresenta ou assiste outra pessoa ao receber esta o sacramento do batismo, crisma, casamento ou da ordem, se se trata de um homem ou ao professar se se trata de uma religiosa" // 3 fig. A que favorece ou protege a outra pessoa nas suas pretensōes, progressos ou designios. 24 Ironicamente, o protetor é aqui dominador. A zona semântica de religiosidade a que corresponde esta denominação, reforça o nexo assinalado entre religiosidade e domínio.

2.1.5. - Definição e configuração da relação actancial.

Ela se define como a interação da absoluta autoridade do "dominador" e o total acatamento dos "dominados"; esta última atitude é especialmente ostensiva em Macario, o herói do relato. Corresponde esta relação à fórmula: "domínio vs. acatamento" que representaremos assim: a vs b.

Importa mostrar que a inconsciência de Macario é relativa não somente ao seu atuar como também à sua condiçāo de "dominado"; daí a satisfação com que aceita sua situação: "No, mi madrina me trata bien. Por eso estoy muy contento en su casa" (p. 10). A fórmula acima, pode, então, completar-se do seguinte modo: (a vs b) $+(-c)$

0 fato de que a perspectiva de Macario seja a única que informa o relato e que ele seja o ator principal, permite o realce do atuar do actante "dominado" e de sua visão do mundo.

2.1.6. - Função deste relato em relação à oposição que nos ocupa. Macario cumpre, no nosso entender, uma função representativa ou simbólica c não ć casual o seu lugar inicial em El llano en llamas. Neste relato, a oposiçāo "dominador - dominado" está mascarada e tornada natural pela índole psicótica do ator principal (dominado), que parece exigir sua sujeiçāo à autoridade do outro.

24 DICCIONARIO de la lengua española. Madriđ Real Academia Española, 1956. 
A visão ideológica somente poderá ser captada neste nível simbólico: a autoridade do "dominador" é ilimitada. O "dominado" é inconsciente de sua situaçāo e está agradecido ao "dominador"; mesmo quando instintivamente lhe atribui certa malignidade. Em meio à sua precariedade os dominados se prestam ajuda mútua. A religião afiança a relação "dominador-dominado".

2.2. Nos han dado la ticrra (Deram-nos a terra)

2.2.1. Atualizaçāo de oposiçāo actancial.

Dominador $<\begin{aligned} & 0 \text { governo } \\ & \text { o senhor delegado } \ldots \ldots \ldots \ldots . . . . \text { intermediário }\end{aligned}$ Dominado camponeses sem terra

O actante "dominador" está concretizado num poder impessoal;

o Governo, que se manifesta por um intermediário: o delegado.

O actante "dominado" se atualiza num ator colctivo, representado no título do relato pelo termo "nos".

2.2.2. - Os atores dominados

a) São certamente personagens normais, mas terão uma sutil analogia com Macario: a inconsciência de sua verdadeira situação de dominados ou explorados.

b) Tal inconsciência os leva a flutuar entre os polos: aparência e realidade, 25 num jogo entre ambas as categorias: os dominados, salvo a narrador, se movem num plano de aparências. Veêm claros somente naquilo que se relaciona com a terra. O narrador homodiegético introduz em várias oportunidades a perspectiva real que imporá ao final do relato. Perspectiva real aparece enfatizada em virtude de uma clara oposição que o texto configura entre o âmbito recebido ("planalto") e o âmbito desejado (a terra fértil);

Contudo, eu sei que desde que era moço, não vi nunca chover no planalto, o que se chama chover. Não, o planalto não é uma coisa que sirva. Não tem nem coelhos, nem pássaros. Não tem nada. A nāo ser umas quantas árvores sem valor $\mathrm{e}$ uma que outra manchinha de pasto com as folhas enroscadas; a nāo ser isto, não há nada... Não esse duro couro de vaca que se chama o planalto. 26

25 Greimas e Todorov empregam a oposiçāo "ser vs. parecer". Ver GREIMLAS, A. J. La structure des actants du recit. In: _—. Du sens. Paris, Seuil, 1970. p. 250; TODOROV, T. Las categorias del relato literario. In: ANALISIS estructural del relato. Buenos Aires, Tiempo Contemporáneo, $1970.280 \mathrm{p}$.

26 "Con todo, yo sé que desde que yo era muchacho, no vi llover nunca sobre el llano, lo que se llama llover. No, el llano no es cosa que sirva. No hay conejos ni pájaros. No hay nada. A no ser unos quantos huizaches trespeleques y una que otra manchita zacate con las hojas enroscadas; a no ser eso, no hay nada" (p. 16) "No ese duro pellejo de vaca que se llama el llano" (p. 17). 
A boa terra está junto ao rio, nela crescem árvores, ali há um povoado. Duas fórmulas inconciliáveis sublinham esta oposiçāo entre terra e planalto: "Del pueblo para acá" (lo dado), "del río para allá". (lo deseado).

2.2.2.1. Predominio da aparência nos atores.

2.2.2.1.1. 1) O título do rclato mostra ironicamente que eles se sentem os alegres receptores de uma dádiva que na verdade nāo existe.

2.2.2.1.2. 2) Para esses atores, o povoado longínquo aparecerá desde o começo do relato como uma esperança. O assunto suscita intencionalmente no leitor, o mesmo efeito, isto $e$, o faz compartilhar a estimativa dos atores. Bem mais adiantc. fazendo uso do recurso do retardamento, destinado a provocar um efeito de ruptura irônica. o leitor percebe que pouco importa que no final do planalto crestado exista um povoado, pois o dado é exclusivamente este planalto: "Porque nos deram a nós esta crosta de terra esteril para que semeáramos". 27

O leitor assume lucidamente a realidade instaurada, isto nāo acontece com os atores "dominados", o que suscita uma ironia dramática.

2.2.2.1.3. No desenlace do relato, o grupo chega ao povoado e nele penetra prazenteiramente. $O$ entusiasmo. absolutamente infundado, se reflete no emprego reiterado da expressāo "nos gusta" (nos agrada) e sua variante "muy a guisto" (muito a gosto):

A medida que descemos, a terra vai ficando melhor. De nossos pés sobe o. pó como se fora uma récua de mulas o que descia por ali; mas nos agrada 28 encher-nos de pó. Nos agrada. Depois de vir durante onze horas pisando a dureza do planalto, nos sentimos muito a gosto envoltos naquela coisa que brinca sobre nós e sabe a terra. Acima do rio, sobre as copas verdes das casuarinas, voam infinidades de cigarras verdes. Isto também é o que nos agrada. 29

O relato alcança assim o clímax de ironia, que vai manter até o seu desenlace; essa terra fértil. onde há um rio e casas é o lugar apreciado que nunca vai pertencer-lhes. As últimas frases mostram os atores jubilosamente alienados.

27 "Porque a nosotros nos dieron esta costra de tapetate para que sembraramos" (p. 17).

280 grifo é nosso.

29 "Conforme bajamos, la tierra se hace buena. Sube polvo desde nosotros como si fuera un atajo de mulas lo que bajara por alli; pero nos gusta llenarnos de polvo. Nos gusta. Después de venir durante once horas pisando la dureza del llano, nos sentimos muy a gusto envueltos en aquella cosa que brinca sobre nosotros y sabe a tierra. Por encima del rio, sobre las copas verdes de las casuarinas, vuelan parvadas de chacales verdes. Eso también es lo que nos gusta" p. 20) 
“- Por aqui me dirijo eu! - nos diz Esteban".30 A afirmação final do narrador situa o leitor na realidade: "A terra que nos deram está lá em cima". 31

\subsubsection{Preclomínio da realidade nos atores.}

2.2.2.2.1. Conhecimento certo que os atores sustentam a respeito da natureza: "[...] a terra está deslavada, dura. Não acreditamos que o arado se enterre nessa como pedreira que é a terra do planalto Teria que se fazer buracos com o enxadão para semear a semente e nem assim é possivel que nasça alguma coisa; nem milho, nem nada vai nascer". 32

2.2.2.2.2. Lucidez do narrador $\mathrm{em}$ contraste com a alienaçāo dos outros dominados:

a) Quando Melitón diz: "Esta é a terra que nos deram", o narrador pensa: "Melitón não está com a cabeça no lugar. Deve ser o calor que o leva a falar assim. O calor que passou pelo chapéu e lhe esquentou a cabeça. E se nāo, por que está dizendo isto? que terra nos deram Melitón? Aqui não tem nem um pouquinho do que prec saria o vento para brincar de redemoinho". 33 b) O narrador alcarı̧̧a um instante de máxima frustração quando diz: "Assim nos deram esta terra". 34

O termo "assim" condena todos os fatores em virtude dos quais só ironicamente cabe afirmar que se recebeu uma dádiva; aponta a situação absurda configurada e promove sua denúncia.

2.2.2.2.3. Acatam absolutamente o que se lhes impōem:

a) O narrador homodiegético - como já mostramos, o mais lúcido dos dominados - descreve com objetividade e progressiva redução do grupo e o despojamento de que são objeto por parte do "dominadores" (aos quais alude como uma força impessoal). Por meio de seu discurso se adverte total acatamento, assunção e incapacidade para entender o que verdadeiramente acontece: "Há pouco, pelas onze. éramos vinte e tantos; mas pouquinho a pouquinho se foram dispersando até ficar nada mais do que csta

30 " - Por aqui arriendo yo! - nos dice Esteban" (p. 20)

31 "La tierra que nos han dado está allá arriba" (p. 20)

32 “... la tierra está deslavada, dura. No creemos que el arado se entierre en esa como cantera que es la tierra del llano. Habria que hacer agujeros con el azadón para sembrar la semilla y ni aun asi es posible que nazca nada; ni maíz ni nada nacerá" (p. 18)

33 "Esta es la tierra que nos han dado". "Melicón no tiene la cabeza em su lugar. Ha de ser el calor lo que le hace hablar asi. El calor que le ha traspasado el sombrero y le ha calentado la cabeza. Y si no, ? por qué dice lo que dice? Cuál tierra nos han dado Meiitón? Aquí no hay ni la tantita que necesitaría el viento para jugar a los remolinos" (p. 19)

34 "Asi nos han dado esta tierra" (p. 18) 
nó que somos nós". 35 "Eu sempre pensei que isso de tirar-nos a carabina fizeram bem. Por aqui acaba sendo perigoso andar armado... Mas também nos tiraram com a carabina, os cavalos". 36 A reação indignada, inexistente no grupo, vai ser suscitada no leitor virtual.

b) Quando o delegado se nega a escutá-los, o grupo reage: "- Espere. senhor delegado. Nós nāo dissemos nada contra o Centro. Tudo é contra o planalto... Não se pode contra o que não se pode. Isso foi o que dissemos... Espere, que vamos explicar. Olhe, vamos começar de onde estávamos..." 37 Acaba se tornando sugestiva e absurda a substituição que o grupo realiza: a culpa é atribuída à natureza, a qual, ainda que imutável como o governo, nāo pode tomar represálias.

2.2.3. - Os atores dominadores.

2.2.3.1. Os dominadores, que no título aparecem apontados ironicamente como os benfeitores ou doadores, são frequientemente referidos de maneira impessoal, o que os faz mais distantes e inacessiveis: "nos quitaron" (nos tiraram) p. 17, "nos dieram" (nos deram) p. 17. "no nos desejaram decir nuestras cosas" (näo nos deixaram dizer nossas coisas). p. 17, "nos han dado" (nos deram) p. 18 e 19.

2.2.2.3.2. O Governo aparece como autoridade onipotente, doadora de bens, infalivel.

2.2.3.3. O delegado, representante do governo, desloca a responsabilidade deste último até o latifúndio. Responde aos "dominados" quando cstes expõem os problemas da planície: "Façam a manifestação por escrito. E agora vão embora. $E$ ao latifúndio que devem atacar, não ao governo que lhes dá a terra". $38 \mathrm{E}$ se nega a escutar aos camponeses: "Mas ele não nos quis ouvir". 39

35 "Hace rato, como a eso de las once, éramos veintitantos; pero puñito a puñito se han ido desperdigando hasta quedar nada más que este nudo que somos nosotros" (15).

36 "Yo siempre he pensado que en eso de quitarnos la carabina hicieron blen. Par acá resulta peligroso andar armado... Pero también nos quitaron los caballos junto con la carabina" (p. 17)

37 " - Espérenos usted. señor delegado. Nosotros no hemos dicho nada en contra el centro. Todo es contra el llano... No se puede contra lo que no se puede. Eso es lo que hemos dicho... Espérenos usted para explicar-le Mire, vamos a comenzar por donde ibamos..." (p. 18)

38 " Eso manifiéstelo por escrito. Y ahora váyanse. Es el latifundio al que tienen que atacar, no al Gobierno que les da la tierra" (p. 18)

39 "Pero él no nos quiso oír" (p. 39). Emilio Miró destaca a critica social y politica evidente en Nos han dado la tierra, aludindo a: "la autoridad, el funcionario impersonal. anónimo, símbolo de la injusticia". MIRÓ. Juan Rulfo In: GIACOMAN, p. 218. Donald $K$. Gordon realisa uma fina anślise do diálogo que se desenvolvo entre os camponeses e o delegado: "O encontro com o delegado do governo é revelador. Em primeiro lugar, ele tinha vindo não para discutir mas para colocar os papéis - sempre os papéis - em suas mãos. O que se les está outorgando 
2.2.4. Correlato bíblico

A assunçāo de um correlato bíblico, sugerido pclo relato, reafirmaria nossa interpretaçāo. Referimo-nos ao tópico da Terra Prometida, desenvolvido no Gênesis e Exodo. Já o título pareceria equiparar os "doadores" nāo especificados com o Deus doador do Gênesis: "E a ti te darei a aos teus filhos depois de ti, a terra de tuas percgrinaçöes, toda a terra de Canaā em herança perpétua; e serci Deus deles". 40

A onipotência do Governo - já referida - o torna comparável a Deus. E o Governo nem sequer se apresenta, como o Deus bíblico, senão mediante um representante: o senhor delegado.

A confiança oscilante dos "beneficiários" acaba sendo, por sua ingenuidade alienada, uma paródia da fé. No Exodo, a Terra Prometida aparce como "terra que destila leite e mel". A comparaçāo entre estes atributos e os atributos do planalto recebida aumentará o efeito irônico.

Destacamos em nossa análise - e isto adquire mais vigor mediante o contraste com o correlato bíblico - que a terra dada ć paradoxalmente a terra nāo dada. Lembre-se a respeito a reação do narrador: "Qual terra nos deram Melitón? Aqui não tem nem um pouquinho do que necessitaria o vento para brincar de redemoinho". 41

Na Biblia, a passagem pelo deserto dura quarenta anos, mas leva à Terra Prometida. No relato, o deserto bíblico passou a ser a meta real, a dádiva outorgada. Mostramos que os beneficiários pretendem, ilusoriamente, transformar o planalto em passagem para um lugar melhor; o que explica a atitude esperançosa e cheia de júbilo do começo do relato, que numa segunda leitura suscitará ironia; o leitor já sabe nesta nova leitura que nada haverá para o grupo depois desse planalto e que a esperança é um auto-engano.

o planalto. Os camponeses estāo cruelmente conscientes de sua imensidão estéril; sua reação a isto se reflete ortograficamente nas maiusculas utilizadas para a palavra "Llano": "Nós perguntamos: - ? O planalto? (p. 17). O delegado parece por énfase na idéia da imensidão quando na sua resposta também utiliza maiúsculas: "Todo el Llano grande" (Todo o grande planalto). Nesta resposta, no entanto, existe um elemento de ironia. A idéia de infertilidade que predomina no uso de "el llanc" por parte dos camponeses falta no uso da mesma palavra por parte do delegado, pois a imensidāo parece ser o significado central de seu comentário. A ilonia logo se faz mais explícita quando ele diz: "No se vayan a asustar por tener tanto terreno para ustedes solos" (Não se assustem por ter tanto terreno só para vocês) (p. 18). GORDON, Donald $K$. El arte narrativo en tres cuentos de Rulfo. In: GIACOMAN, p. 354 .

40 BIBLIA. A. T. Gênesis XVII, 8. La santa Biblia; antiguo y nuevo testamento. s.1., Sottedades Blblicas Unidas, 1957. p. 14

4) ?Cuál tierra nos han dado, Melitón? Aquí no hay ni la tantita que necesitaria el viento para jugar a los remolinos" (p. 19) 
o contraste com o correlato bíblico acentua o efeito irônico em função de uma ideologia: os beneficiários são os explorados e os beneficiadores, os exploradores.

2.2.5. Definiçāo e configuração da relação actancial.

Corresponde à mesma definição que mostramos no que se refere ao conto Macario: (a vs b) $+(-c)$

O narrador homodiegético, também neste relato, pertence aos "dominados"; estes, por intermédio dele, informam ao mundo a partir de sua perspectiva, se manifestam prontamente e adquirem grande relevo.

2.2.6. Funçāo deste rclato em relação à oposição que nos ocupa. Neste segundo relato, se realiza a passagem da oposição "dominador-dominado" do âmbito figurado ao literal. O dominador, de pessoal se faz impessoal e se vale de um intermediário. O dominado, de individual passa a ser coletivo. ${ }^{42} \mathrm{~A}$ denúncia ideológica se desmascara: a dominação aparece despojada de toda justificação; atores dominados - cuja conduta em alguns aspectos é análoga à do ator psicótico do relato inaugural - são os exploradores típicos. Trata-se de camponeses inconscientes de seus direitos $\mathrm{e}$ do domínio que é exercido sobre eles. $\mathrm{O}$ único âmbito a respeito do qual têm certeza ć a terra e a ela culpam como fonte de seus males.

O Governo delega seu poder a um funcionário. Aparece o latifundio como outra instituiçāo dominante, a qual o delegado torna responsável pela situaçāo dos dominados.

2.3. La cuesta de las comadres (A encosta das comadres)

2.3.1. Atualização da oposição actancial

Dominador: Odilón e Remigio Torrico (latifundiários)

Dominado: os habitantes da Encosta das Comadres: o narrador

$$
\text { liomodiegético }\left\{\begin{array}{l}
\text { adjuvante dos dominadores } \\
\text { oponente dos dominadores }
\end{array}\right.
$$

O actante "dominador" está atualizado por dois atores: os irmãos Odilón e Remigio Torrico. O actante "dominado" está representado, como em Nos han dado la tierra por um ator de indole coletiva: os habitantes da Encosta das Comadres. Entre estes últimos teria que se destacar como configurador de uma categoria especial - o narrador homodiegético, ator sincrético que engloba três actantes: dominado, adjuvante, oponente.

\subsubsection{Os atores dominados}

42 Donald K. Gordon adverte adequadamente sobre este aspecto, comparando Macario e Nos han dado la tierra: "Se en "Macario" Rulfo nos faz sentír a desolação de toda uma vida, em "Nos han dado la ticrra" (publicado na mesma época que "Macario") nos (az perceber as adversidades e privaçōes de um setor machucado do povo". GORDON, p. 353 
Os "dominados" sustentam, com respeito aos "dominadores", a atitude de total acatamento já conhecida, à qual se unirá agora o desmascaramento da reação negativa que os dominadores suscitam: ódio e temor.

2.3.2.1. Accita-se sem nenhuma reação que os Torricos tivessem se apropriado de toda a Encosta das Comadres: "com tudo isto, quando houve a distribuição, a maior parte da Encosta das Comadres nos tinha sido dada a todos igualmente, aos sessenta que ali vivíamos e a eles, aos Torricos, nada mais que um pedaço de mato com umas piteiras, nada mais, porém onde estavam dispersadas quase todas as casas. Apesar disso a Encosta das Comadres era dos Torricos. A chácara em que eu trabalhava também era deles: de Odilón e Remigio Torrico e a dúzia e meia de lombas verdes que se viam lá embaixo eram também deles. Não precisava averiguar nada. Todo o mundo sabia que era assim. ${ }^{43}$

2.3.2.2. Sem lutar, os habitantes da Encosta das Comadres vāo embora do lugar: "Iam-se de boca calada, sem dizer nada nem brigar com ningućm. E certo que lhes sobrava vontade de brigar com Torricos, para vingar-se de todo o mal que lhes haviam feito; mas nāo tiveram ânimo".44

2.3.2.3. Quando os Torricos abandonavam por uns tempos a Encosta das Comadres, o lugar revivia; seu retorno, ao contrário, suscitava temor, o que é assinalado explicitamente pelo narrador: "Sempre foi assim o medo que trazia os defuntos Torricos cada vez que regressavam à Encosta das Comadres". 45

2.3.2.4. O narrador cujo caráter sincrético já mencionamos, enfatiza em seu relato a ausência de temor dos Torricos e insiste na amizade que o une a eles (traços que o diferenciam dos outros dominados). "Os DEFUNTOS Torricos sempre foram bons amigos meus", 46 "no que se refere a mim, sempre foram bons amigos

43 "... con todo y que, cuando el reparto. la mayor parte de la cuesta de las Comadres nos había tocado a todos por igua: a los sessenta que alli viviamos, y a ellos, a los Torricos, nada más que un pedazo de monte. con una mezcalera nada más, pero donde estaban desperdigadas casi todas las casas. A pesar de eso, la Cuesta de las Coniadres era de los Torricos. El coamil que yo trabajaba era también de ellos: de Odilón e Remigio Torrisco, y la docena y media de lomas verdes que se veian abajo eran juntamente de ellos. No habís por qué averiguar nada. Todo mundo sabía que así era" (p. 21) O grifo neste texto assim como nos seguintes é nosso.

44 "Se iban callados la boca, sin decir nada ni pelearse con nadie. Es seguro que les sobraban ias ganas de pelearse con ios Torricos para desquitarse de todo el mal que les habian hecho; pero no tuvieron ánimos" (p. 44)

45 "Siempre fue asi el miedo que traían los difuntos Torricos cada vez que regresaban a la Cuesta de las Comadres" (p. 24)

46 "Los DIFUNTOS Torricos siempre fueron buenos amigos mios" (p. 21) 
até um pouquinho antes de morrer", 47 "e além disso cra bom amigo dos Torricos", 48 "Era bom amigo dos dois". 49 Esta relação parece reforçada na perspectiva de Remigio que diz ao narrador: "mas era tāo amigo meu o meu irmāo como tu". 50 Amizade que o leva a atuar como ajudante dos Torricos: "Era um bom amigo dos dois e às vezes gostaria de ser um pouco menos velho para me meter nos trabalhos em que eles andavam. Entretanto eu já não servia para muito. Dei-me conta naquela noite em que os ajudei a roubar um arrieiro". 51

2.3.2.5. O relato configura uma nova faceta: a morte de ambos os dominadorcs. Odilón morre nas māos da família dos Alcaraces, em Zapotlán e o narrador presencia sua morte. Remigio é assassinado pelo próprio narrador. Importa destacar que não se trata $\mathrm{cm}$ absoluto de planos de reinvidicação racionalmente elaborados, mas de atos impulsivos e semicasuais mostrados num nível de quase absurdo.

2.3.2.6. Interessa comparar $\mathrm{em}$ relação ao tema que nos ocupa o grau de conhecimento deste narrador com o que possuiam Macario e o narrador de "Nos han dado la ticrra"; estes dois últimos sabem menos que o leitor virtual, o que origina um efeito de ironia dramática; o narrador da Encosta das Comadres sabe mais que o leitor virtual, sobre quem exerce, talvez, uma certa atitude irônica. O narrador conhece perfeitamente o acontecido, mas no seu discurso obedecerá a uma tendência atenuadora e a um afã de elisão, que vai provocar a disfiguração dos fcitos no relato. Propomos a este respeito uma dupla interpretação:

a) Ironia desenvolvida intencionalmente pelo narrador, que é exercida sobre o leitor virtual.

b) Estes momentos corresponderiam a uma perspectiva literal e não irônica; em todo o caso, seria o próprio narrador o ironizado e revelariam a limitação do narrador em oposição a seu alto grau de conhecimento; mostrariam sua dificuldade para mensurar e lograr uma adequada compreensão dos acontecimentos que narra, traço distintivo de certos atores de Rulfo (Sem dúvida esta limitação que, por momentos - o assassinato de Remigio Torrico, por exemplo - chega à infra-humanidade, aproxima este narrador "normal" de Macario).

47 “... pelo lo que es de $\mathrm{mI}$, siempre fueron buenos amigos, hasta tantito antes de morirse" (p. 21)

48 "... y además era buen amigo de los Torricos" (p. 22)

49 "Era buens amigos de los dos" (p. 24)

50 "... pero era tan amigo mío mi hermano como tú" (p. 27)

51 "Era buen amigo de los dos y a veces hubiera querido ser un poco menos viejo para meterme en los trabajos en que elios andan. Sin embargo, ya ni servia yo para mucho. Me di cuenta aquella noche en que les ayudé a robar a un arriero" (p. 24) 
Admitimos ambas as interpretaçōes e estimamos que a ambigüidade acrescenta riqueza ao rclato. As frases selecionadas por nós como exemplo do proposto, poderão, pois ser captadas como manifestação irônica do narrador e/ou limitaçāo compreensivo-associativo do mesmo.

- "Talvez em Zapotlán não gostassem deles". 52 Enfatizamos o matriz dubitativo que contrasta com a realidade configurada. Esta frase está em oposição a outras que o narrador dirige a Remigio: "Começando, porque Odilón não devia ter ido a Zapotlán. Isso tu sabes. Cedo ou tarde tinha que lhe acontecer algo nesse povoado, onde havia tantos que se lembravam muito dele. E tampouco os Alcaraces gostavam deles". 53 Esta última frase reflete a tendência eufemística do narrador. - $O$ caso é que de mim sempre foram bons amigos, até um pouquinho antes de morrer". 54 Nesse breve tempo aludido, o narrador assassinou Remigio e presenciou, sem intervir na sua defesa, o assassinato de Odilón.

- "Agora isso de que não gostassem deles em Zapotlán não tinha nenhuma importâncla, porque tampouco gostavam de mim e acredito que ninguém dos que viviam na Encosta das Comadres era visto com bons olhos pelos de Zapotlán". 55 Estas frases intensificam o efeito atenuador do primeiro exemplo citado e ocultam a evidência outorgada pelo relato comum segundo o qual há razōes especiais para odiar aos Torricos em Zapotlán.

- "Por outro lado, na Encosta das Comadres, os Torricos não se davam bem com ninguém". $56 \mathrm{Na}$ Encosta das Comadres, os Torricos são odiados por todos, salvo pelo narrador.

- "No entanto, daquele tempo para cá, a Encosta das Comadres se foi desabitando".57 A expressão adversativa suscita uma ruptura lógica; dada a realidade configurada, conviria substituí-la por uma expressão causal como: "devido a isto" (devido a cllo), "por causa disto" (a causa de ello).

52 "- Tal vez en Zapotlán no los quisieran;" (p. 21)

53 "comenzando porque Odilón no debia haber ido a Zapotlán. Eso tú lo sabes. Tarde o temprano tenía que pasarle algo en ese pueblo, donde habia tantos que se acordaban mucho de él. Y tampoco los Alcaraces lo querian" (p. 29)

54 “... lo que es de $\mathrm{mi}$ siempre fueron buenos amigos, hasta tantito antes de morirse" (p. 21)

65 "Ahora eso de que nos $10 \mathrm{~S}$ quisieran en Zapotlan no tenia ninguna importancia, porque tampouco a mi me querian alli, y tengo entendido que a nadie de los que viviamos en la Cuesta de las Comadres nos pudieron ver con buenos ojos los de Zapotlán" p. 21)

56 "Por otra parte en la Cuesta de las Comadres, los Torricos no la llevaban bien con todo mundo" (p. 21)

57 "Sin embargo, de aquellos dias a esta parte, la Cuesta de las Comadres se habia ido deshabitando" (p. 21) 
2.3.3. Os atores dominadores.

Os Torricos são forasteiros que chegam a encarnar o poder do latifúndio. Assim como nos "dominadores" dos relatos precedente, nos Torricos se unem o poder econômico e a autoridade; esta última exercida em grau tal que sāo na verdade donos da vida dos demais. Odilón bate na cabeça de um arrieiro e o mata. $O$ ato não assume nenhuma transcedência.

"Está bem morto, tornei a repetir.

- Não, nāo acredites, apenas está um pouquinho atarantado porque Odilón the bateu com um pau na cabeça, mas logo depois se levantará. Já vais ver que quando sair o sol e ele sentir o calorzinho vai se levantar muito depressa e irá logo para casa. Pega este fardo dai e vamos embora! - Foi tudo o que me disseram. Já por fim lhe dei uma última patada ao mortinho e soou como se a tivesse dado num tronco seco". 58

Remigio diz ao narrador: "Odilón e eu éramos senvergonhas c tudo o que quizcres e não digo que não chegamos a matar ninguém; mas nunca o fizemos por tāo pouco". 59

2.3.4. Definiçāo e configuração da relação actancial.

Persiste a definiçāo já assinalada: (a vsb). Esta submissão existe ainda quando há nos dominados uma clara consciência de sua situação e uma reação emotiva negativa diante dela. A fórmula correspondente é: (a vs b) + (c).

0 narrador homodiegético pertence ao âmbito dos dominados. tal como nos relatos anteriores e é sua perspectiva a que se impõe; sua relação com respeito aos dominadores é mais complexa: cumpre também com respeito a eles a funçāo actancial de adjuvante (amigo) e oponente (assassino de um dos dominadores).

2.3.5. Funçāo deste relato em relaçāo à oposição que nos ocupa:

A inconsciência de Macario c dos camponeses de "Nos han dado la tierra" é nesse relato substituída por uma atitude consciente dos dominados com respeito à sua situação; esta consciência suscita neles determinados sentimentos com respeito aos "dominadores": ódio e temor. O que nāo vai se traduzir num plano racional para acabar com a dominação:

58 " - Está bien muerto - les volvi a decir.

- No, no te creas. nomás está tantito atarantado porque Odilón le dio con un leño en la cabeza, pero después se levantará. Ya verás que en cuanto salga el sol y sienta el calorcito, se levantará muy aprisa y se irá enseguida para su casa. ! Agárrate ese tercio de all y vámonos! - Fue todo lo que me dijeron.

Ya por último le di un última patada al muertito y sonó igual que si se le hubiera dado a un tronco seco" (p. 25)

59 "Odilón y yo érmos sinverguienzas y lo que tú quieras y no digo que ni llegamos a matar a nadie; pero nunca lo hicimos por tan poco" (p. 28) 
O actante "dominado" continua sendo representado por um grupo - tal como em Nos han dado la tierra; porém o actante dominador deixou de estar concretizado numa força impessoal e está encarnado em dois atores.

o relato incorpora a morte de um dos dominadores isto $\dot{c}$ destacado mediante o qualificativo DIFUNTOS na primeira frase do corpo do texto. Os assassinatos dos Torricos são eventos quase fortuitos, o que atenua seu possível caráter de ato de rebeldia. $O$ assassinato de Remigio corresponde ao âmbito dos dominados (o narrador homodiegético) não assim os Alcaraces, assassinos de Odilón.

A função ideológica do relato é evidente: o poder arbitrário e injusto dos Torricos, ladrōes de terras, a situaçāo precária dos que nada possuem, a infra-humanidade do narrador, suscitam uma intensa reação virtual.

2.4. El hombre (O homem)

2.4.1. Atualizaçāo da oposição actancial

Dominador: Licenciado: representante do sistema juridico vigente (destinatário ou receptor homodiegético)

Dominado: Borregueiro (narrador homodiegético)

"Dominador" e "dominado" se manifestam respectivamente num ator individual. O aparecimento desta oposição actancial ocorre numa segunda parte do relato, na qual se produz uma mudança da situação narrativa (narrador e destinatário heterodiegético (1.* parte) $\ldots \ldots \ldots,>$ narrador e destinatário homodiegético (2.* parte)).

2.4.2. $\mathrm{O}$ ator dominado

a) $\mathrm{O}$ borregueiro sabe menos da realidade configurada que o leitor virtual (não conhece os acontecimentos referidos na primeira parte do relato) mas se diferencia de Macario e dos camponeses de Nos han dado la tierra na medida em que essa deficiência é meramente informativa e não compreensiva ou valorativa. Tem absoluta consciência de sua própria redução, determinada esta pela sua posição social e assim o manifesta discursivamente: "Mas nāo sou adivinho, senhor licenciado, sou apenas um cuidador de borregos e até, se o senhor quizer, um pouco temeroso do que está acontecendo". 60 "Mas a gente é ignorante. A gente vive trepado no cerro, sem mais trato que os borregos e os borregos não sabem dos mexericos". $€ 1$ "Eu não sou nada mais do que

60 "Pero no soy adivino señor licenciado sólo soy un cuidador de borregos y hasta si usted quiere algo miedoso cuando de la ocasión" (p. 44). Este grifo e os seguintes sāo nossos.

61 "Pero uno es ignorante. Uno vive remontado en el cerro, sin más trato que los borregos y los borregos no saben de chismes" (p. 45) 
um borreguciro e além disso não sei nada".62 "Sou borrcgueiro e nāo sei de outras coisas". 63

A consciência do borreguciro - assim como acontece com a inconsciência dos outros dominados - suscita acatamento e anula toda possibilidade de rebelião.

2.4.2.2. O desenvolvimento diegético confirma a consciência que o borreguciro tem de sua insignificância e precariedade. Scm que lhe haja correspondido nenhuma participação na morte do homem, foi acusado de encobridor pclo licenciado e ameaçado com a prisão; o relato permite supor que o borregueiro não terá nenhuma possibilidade de se salvar do castigo injusto. Mais ainda, o borrcgueiro chega a justificar o seu acusador: "Ainda, que, como o senhor diz, pude muito bem tế-lo agarrado desprevenido e uma pedrada bem dada na cabeça o teria deixado alí duro. 0 senhor sem nenhuma dúvida tem razāo".64

2.4.2.3. Desde o tempo do narrado pelo borregueiro (șeu contato com o "homem"), até o tempo da narraçāo, parece ter havido no borregueiro uma mudança (isto segundo a perspectiva do próprio autor): o passo da ignorância ao conhecimento, graças à informaçāo do licenciado. Sob influência deste, o borregueiro afirma que se tivesse sabido dos fatos, teria agido de forma diferente e assume uma forte atitude de condenaçăo com referência ao "homem"; e de auto-crítica: "Oxalá mo dessem agora. Sabendo o que tinha feito o teria esmagado a pedradas e nem sequer ficaria com remorsos".65 "Isso que me conta de todas as mortes que devia e que acaba de efetuar não me perdoo. Gosto de matar capangas. Nāo é meu costume; mas a gente deve se sentir bem ajudando a Deus a acabar com esses filhos do mal". 66 "A coisa $\dot{c}$ que nem tudo ficou nisso. Eu o vi chegar novamente o dia seguinte. Mas ainda não sabia de nada. De tê-lo sabido". 67 "O senhor diz que matou todinha a familia dos Urquidi? Se eu tivesse sabido o imobilizaria a puro lenhazos".68 "Mas o senhor

62 "Y o no soy más que un borreguero y de ahí en más no sé nada" ( $p$. 46)

63 "Soy borreguero y no sé de otras cosas" (p. 47)

64 "Aunque, como usted dice. lo pude muy bien agarrar desprevenido y una pedrada bien dada en la cabeza Io nubiera dejado alli tieso. Usted ni quién se lo quite que tiene la razón" (p. 44)

65 "Que me lo dieran ahorita. De saber lo que habia hecho lo hubiera apachurrado a pedradas y ni siquiera me entraria el remordimiento" (p. 44)

66 Fiso que me cuenta de todas las muertes que debia y que acaba de efetuar. no me lo perdono. Me gusta matar matones, créame. No es la costumbre; pero se ha de sentir sabroso ayudario a Dios a acabar con esos hijos del mal" p. 44)

67 "La cosa es que no todo quedó alli. Lo vi venir de nueva cuenta al día siguinte. Pero yo todavia no sabia nada. ! De haberlo sabido! p. 44)

68 "? Dice usted que mató a toditita la familia de los Urquidi? De haberlo sabido lo atajo a puros leñazos" (p. 45) 
diz que acabou com a vida dessa gente. Se eu tivesse sabido. 0 que é ser ignorante e confiado".69

A reação do borregueiro talvez possa explicar-se por uma necessidade defensiva; este fato não implica que ponhamos em dúvida a sua ingenuidade e seu absoluto acatamento à posição do licenciado.

2.4.2.4. E importante destacar que o borrcguciro, em que pese a sua limitação ou por causa dela, é capaz de captar uma faceta do "homem" precaria e humana; isto em oposição à imagem despiedade que dele forja o licenciado e que o borregueiro recebe e proclama: "Mas não parecia mau. Me contava de sua mulher e de seus guris e de quão longe que estava deles. Fungava o ranho ao lembrar-se deles". 70 "Ele somente me pedia de comer e conversava sobre os seus filhos jorrando lágrimas".71

2.4.3. O ator dominador.

O licenciado só está presente no relato por meio das frases do borregueiro, que a ele se dirige, nomeando-o. A ausência de participação direta do licenciado faz com que esta segunda parte apareça como um grande monólogo dirigido a um locutor impessoal, inalcançável e inalterável, encarnaçāo do poder, o que dá maior ênfase à impotência do borreguciro.

2.4.4. - Definição e configuraçāo da relação actancial.

Corresponde à seguinte difiniçāo: (a vs. b) $+\mathbf{c}+\mathbf{d}$

Que narrador e destinatário sejam homodiegéticos provoca um efeito de simultaniedade na apresentação. A perspectiva que informa o relato é a do ator dominado.

2.4.5. Função deste relato em relação à oposição que nos ocupa.

2.4.5.1. A incorporação da segunda parte deste relato com sua nova situação narrativa está ao serviço da configuração da oposição "dominador-dominado" e de sua projeção ideológica.

2.4.5.2. Este relato significa uma culminaçāo dos seguintes aspectos: a) Intensifica-se a distância que percebemos entre delegado e camponeses de Nos han dado la tierra. Ao contrário do delegado, que se manifesta no texto por meio de seu discurso, o licenciado só estará presente por meio das frases do borregueiro. A impossibilidade de alcançar, de modificar a força dominadora é evidente.

b) O borregueiro é, entre os "dominados" estudados, o mais consciente de sua precariedade pessoal - é o único que, o demons-

69 "Pero dice usted que acabó con la vida de esa gente. De haberlo sabido. Lo que es ser ignorante y confiado" (p. 46)

70 "Pero no parecia malo. Me contaba de su mujer y de sus chamacos y de lo lejos que estaban de él. Se sorbia los mocos al acordar-se de ellos" (p. 46)

71 "El sólo me pedia de comer y me platicaba de sus muchachos, chorreando lágrimas" (p. 46) 
tra discursivamente - a consciência que possui de sua circıınstância determina a absoluta assunção desta.

2.4.5.3. O desenvolvimento diegético patenteia fortemente a injustiça $e$ arbitrariedade de que o "dominado" é objeto; elas se manifestam aqui na atribuiçăo de culpa ao inocente, sem possibilidade de apclação. A autodefesa é impedida pela redução e impotência do borregueiro e pela inaccssibilidade do licenciado.

2.4.5.4. A compreensão que o borregueiro logra das facetas humanas de José Alcancia (" o homem"), pareceria elevar a outro nível, a ajuda que em Macario os "dominados" se prestam entre si; trata-se $\mathrm{cm}$ ambos os casos de uma afinidade possibilitada pela situação compartida.

2.5. En la madrugada ( $\mathrm{Na}$ madrugada)

2.5.1. - Atualizaçāo da oposiçāo actancial

Dominador: Don Justo (latifundiário, "o Patrão")

a autoridade judicial

Dominados: os habitantes de San Gabriel, o velho Esteban (narrador homodiegético).

O actante "dominador" está atualizado por dois atores: um ator individual, pessoal, Don Justo (o patrāo), e um ator impessoal, meramente aludido, ao qual se capta como aliado dos valores que Don Justo representa.

O actante "dominado" está atualizado por um ator coletivo: os habitantes de San Gabriel. O desenvolvimento diegético confere importancia a um desses dominados: o velho Esteban.

\subsubsection{Os atores dominados}

2.5.2.1. O velho Esteban

2.5.2.1.1. Seu ofício é arrear o gado do patrăo

2.5.2.1.2. A precariedade de sua cxistência lembra a de Macario: se faz presente, como no outro relato, o motivo da fome:

"E como nāo ia estar magro se mal comia". 72 Aparece, como Macario, oprimido pelo trabalho que o amo lhe impõc: "Sc eu passava o tempo viajando com as vacas: as levava a Jiquilpan, onde ele tinha comprado um potreiro de pastagem; esperava que comessem e logo as trazia de volta, para chegar com elas de madrugada Aquilo parecia uma eterna peregrinação".73 Aludindo à sua vestimenta, assinala o velhor Esteban: "Eu tinha o umbigo frio de trazê-lo ao ar". $^{n}$.

72 "Y cómo no iba a estar flaco si apenas comia" (p. 53)

73 "Si me la pasaba en un puro viaje con las vacas: las llevaba a Jiquilpan, donde él habia comprado un potrero de pasturas; esperaba a que comieran y luego me las traía de vuelta para llegar con ellas de madrugada. Aquello parecia una eterna peregrinación" (p. 53)

74 "Yo tenía el ombligo frío de tragrio al aire" (p. 49) 
2.5.2.1.3. Scu aniquilamento pessoal - efeito do sistema - recorda também a do psicótico Macario: como este, é inconsciente no que se refere às suas próprias açōes e sua memória é falível; como Macario, não sabe sc matou ou nāo: "É que dizcm que eu o tinha matado, falaram os rumores. Bem pode tcr sido, mas eu não me lembro". 75 Seus destinatários sāo indiferentemente homens ou animais entre os quais parece não fazer discernimento. "Não dissc nada para as vacas, nem thes expliquei nada; fui embora sem que me vissem para que não me fossem seguir". ${ }^{76}$. Sua atitude com o terneiro - acontecimento desencadeante do desenvolvimento diegético deve ser entendida em parte como um efeito deste aniquilamento: " $E$ lhe deu patadas quando viu que mamava das quatro tetas" Te quebrarei o focinho, filho de rês".i7 Aliás tal atitude corresponde a uma fiel imitação da realidade a qual cle está submetido (realidade configurada na base da oposição "dominador - dominado"); realidade que limita suas concessões com acrimonia e não permite transgressōes às normas: "Saboreia, que não são tuas; te darás conta que este leite ć leite terno como para um recém-nascido". E deu-lhe patadas quanto viu que mamava das quatro tetas". $78 \mathrm{O}$ ato de Esteban é, também, manifestação compensadora de uma natural tendência de domínio persistentemente reprimida no ator.

2.5.2.1.4. Sustenta acatamento a uma hierarquia scgundo a qual Don Justo, o patrāo, ć por essência - superior: "Não acredita o senhor que matar a um próximo deixa rastros? Deve deixá-los, e mais ainda se se trata de um superior".79

2.5.2.1.5. Sua incapacidade para reagir diante da situaçāo $\mathrm{cm}$ que foi apanhado como vitima, lembra a do borregueiro de El hombre: "Mas desde $o$ instante $\mathrm{em}$ que me meteram aqui na prisão por algo há de ser. Não acha o senhor?" 80 Chega, inclusive, a justificar seu acusador tal como aconteceu com Macario (Macario) e o borregueiro (El hombre). Não corresponde nem à índole do ator - cuja memória está além disso obnubilada e cuja submissão ao

75 "Y que dizque yo lo habfa matado dijeron los diceres. Bien pudo ser, pero yo no me acuerdo" (p. 51)

76 "Nos les dije nada a las vacas, ni les expliqué nada; me fui sin que me vieran, para que no fueran a seguirme" p. 49)

77 "Y le dio de patadas cuando vio que mamaba de las cuatro tetas "Te romperé las jetas, hijo de res" (p. 50)

78 "Saboréalas nomás, que ya no son tuyas; te darás cuenta que esta leche es leche tierna como para um recién nacido" $\mathbf{Y}$ le dio de patadas cuando vio que mamaba de las cuatro tetas" (p. 50)

79 " ? No cree usted que matar a un prójimo deja rastro? Los debe de dejar, y más tratándose -de un superior de unon (p. 51) o grifo é nosso.

80 "Pero desde el momento que me tienen aqui en ia cárcel por algo ha de ser, ?no cree usted?" (p. 51) 
patrāo o impediria - nem à índole do mundo plasmado, que o velho Esteban argumente assassinato por legítima defesa.

2.5.2.1.6. A religião o ajuda a conformar-se com sua existência, na qual não se percebe um só indício de rebelião:

a) Ao escutar os sinos do amanhecer em San Gabriel, cumpre fielmente o rito, "[...] desce da vaca, ajoelhando-se no chão e fazendo o sinal da cruz com os braços estendidos". 81

b) Seu peculiar agradecimento a Deus, quando pensa que vai ser condenado à morte, mostra que o ator é incapaz de auto-conceder-se à mínima dignidade humana: "A memória, na minha idade, é enganadora; por isso, eu dou graças a Deus, porque, se acabam com todas as minhas faculdades eu não perco muito, já que quase não me fica nenhuma". 82

2.5.3. Os atores dominadores

\subsubsection{Don Justo}

2.5.3.1.1. É, como os Torriscos, um dominador dono de terras; deles porém, se diferencia porque nāo aparece como um forasteiro, um ladrāo de terras, senão como o legítimo proprietário, acatado pelos dominados. Sua categoria de patrão se mostra no tratamento de que é objeto: don Justo. 83

2.5.3.1.2. O nome deste ator nos parece ironicamente sugestivo, pois Don Justo é a encarnação da injustiça, da arbitrariedade.

2.5.3.1.3. No plano literal e simbólico é oferecida uma significativa descrição deste ator quando é tido como "el dueño de la luz" (o dono da luz) (p. 53). A ironia se evidencia em dois planos:

a) Se levamos em conta a simbologia inerente à "luz", ela é tradicionalmente identificada com o espírito, a moralidade, a razão, a intelectualidade, a sabedoria. Na simbologia religiosa, a luz representa Cristo: "Eu sou a luz do mundo: o que me segue não caminha nas trevas, mas terá a luz da vida". 84 Deus é luz ou fonte de luz e habita numa luz inacessivel. 85

81 "... se baja de la vaca, arrodillándose en el suelo y haclendo la sefial de la cruz con los brazos extendidos" (p. 48)

82 "La memoria, a esta edad mía, es engañosa; por eso yo le doy gracias a Dios, porque si acaban con todas mis facultades, yo no pierdo mucho, ya que casi no me queda ninguna" (p. 53)

83 "Don" do latim dominus = senhor. Título honorifico e de dignidade que anteposto somente ao nome próprio, nảo ao sobrenome, se dava antigamente a multo poucos. ainda de primeira nobreza. Depois, tornou-se distintivo de todos os nobres e já năo é negado a nenhuma pessoa de bem". DICCIONARIO de la lengua española, Madrid, Real Academia Española 1956. O grifo é nosso.

84 BIBLIA, San Juan, 812

85 PEREZ RIOJA, J. A. Dicclonario de simbolos y mitos. Madrid, Tecnos, 1962. 
b) O luto não aparece como expressão de dor, mas como um fato iniludível: "Nessa noite nāo acenderam as luzes, de luto, pois don Justo era dono da luz". 86

2.5.3.1.4. O texto mostra o comportamento de don Justo para com seus subordinados por sua atuação com Esteban: "Eu lhe teria quebrado o focinho se não tivesse aparecido ali o patrāo don Justo, que me deu patadas para me acalmar. Me surrou uma sarta de porradas atć que fiquei dormindo entre as pedras, com os ossos estourando de tão safados que estavam. Me lembro que fiquei o dia inteiro fraco e sem poder me mexer do hinchaço que ficou depois o pela dor muito grande que ainda me dura" 87 Don Justo castiga Esteban, irritado com a conduta deste com o bezerro. $\mathrm{Na}$ normal inversão de valores própria do mundo configurado, o bezerro tem mais importância, aos olhos do dominador, que o dominado. Esteban descreve a atitude habitual de don Justo: "Tinha muito mau gênio. Tudo the parecia mal; que os pesebres estavam sujos, que os bebedouros não tinham água. que as vacas estavam magras. Tudo lhe parecia mal; até que eu estivesse magro nāo the agradava". 88

2.5.3.1.5. Configura-se como na Encosta das Comadres a morte do dominador; em ambos os textos se trata de um ato premeditado. Mas sobre esta base comum há diferenças que importa destacar. 89

a) Na Encosta das Comadres, a morte dos Torricos é configurada como puramente casual; nāo caberia adjudicar-lhe uma significação simbólica. Os executores dessas mortes são: Os Alcaraces (não são dominados) e o narrador homodiegético (encontra-se em ambigua relação com os dominadores).

b) No relato que agora nos ocupa, o assassinato de don Justo alcança categoria simbólica: um dominado dá morte a um dominador (aparente alteraçāo da ordem estabelecida). Isto acontece como ato de defesa pessoal e sem consciência por parte do dominado que, aliás, pagará este ato com sua vida.

86 "Esa noche no encendieron las luces, de luto, pues don Justo era dueño de la luz" (p. 53).

87 "Y le hubiera roto el hocico si no hubiers surgido por alli el patrón don Justo, que me dio de patadas a mí para que me calmara. Me zurró una sarta de porrazos hasta que me quedé dormido entre las piedras, con los huesos tronándome de $\tan$ zafados que los tení. Me acuerdo que duré todo ese día entelerido y sin poder moverme por la hinchazón que me resultó después y por el mucho dolor que todavia me dura". (p. 50).

88 Tenía muy mal genio. Todo le parecia mal: que estaban sucios los pesebres, que las pilas no_tenian agua; que las vacas estaban flacas. Todo le parecía mal; hasta que yo estuviera flaco no le gustaba" (p. 53).

89 O texto é ambíguo no que se refere a morte de don Justo; em nossa análise entenderemos que esta morte foi realizada pelo velho Esteban. 
2.5.3.2. A autoridade jurídica

Aparece meramente aludida no relato que Esteban faz a um destinatário não nomeado: "Me mantêm detido na prisão e vão me julgar na semana que vem porque matei don Justo". 90

A forma verbal empregada destaca a impersonalidade deste ator; este traço corresponde a um extremo da impersonalidade do licenciado em El hombre. O mundo delineado, no qual se entende que a autoridade jurídica está aliada aos valores do patrāo, permite esperar um juízo implacável que finalize na pena de morte para o velho Esteban.

2.5.4. Função da religiāo no relato

2.5.4.1. O espaço no qual ocorre a diégese, tem um nome religioso: "São Gabriel". O termo hebreu Gabriel significa "força de Deus". "Gabriel é o guardião do tesouro celestial, o Anjo da Redenção e o supremo mensageiro de Deus. Anunciou à Virgem que ela seria a mãe do Salvador". 91 Se atualizamos este significado, o efeito irônico que surge a partir do relato é incontestável; podemos concentrá-lo na confrontação de dois polos: salvação prometida vs. impossibilidade de salvação.

2.5.4.2. A religião tem sido destacada como paliativo do dominado, que o ajuda a continuar vivendo uma existência dura e oprimida.

2.5.4.3. A Igrcja mesmo constituindo-sc um verdadeiro freio para que o dominador deixe de violar os preccitos religiosos, apenas consegue que a transgressão seja realizada em segredo. Don Justo mantem relaçōes incestuosas com sua sobrinha Margarita: "Se o padre autorizasse eu me casaria com ela; mas estou certo de que armará um escândalo se lhe peço. Dirá que é um incesto e nos excomungará aos dois. Mas vale deixar as coisas em segredo. 92

2.5.5. Definição e configuração da relaçāo actancial

Cumpre-se a fórmula: (a vs. b $+\mathbf{c}+\mathbf{d}$ )

o relato se plasma sob duas perspectivas: a) narrador heterodiegético b) narrador homodiegético; esta última funçāo corresponde ao dominado Esteban; por meio de sua perspectiva intensifica-se a mostra da precariedade e reduçāo do dominado.

2.5.6. Funçāo deste relato em relação à oposição que nos ocupa

2.5.6.1. O relato apresenta dois "dominadores" de natureza diferente, aliados entre sí em prejuízo do "dominado": o patrão e a autoridade jurídica meramente aludida, que decidirá a sorte do acusa-

90 "Me tienen detenido en la cárcel y me van a juzgar la semana que entra porque criminé a don Justo" (p. 53). O grifo é nosso.

91 PEREZ RIOJA, J. A. Diccionario de simbolos y mitos. Madrid. Tecnos. 1962.

92 "Si el señor cura autorizara esto, yo me casarfa con ella; pero estoy seguro de que armará un escándalo si se lo pido. Diŕ́ que es un incesto y nos excomulgará a los dos. Más vale dejar las cosas en secreto" (52).

Leleas, Curifiba (25) : $251-292$, jul. 1976 
do. Com relaçāo a este scgundo "dominador", o traço de impersonalidade que apontamos em Nos han dado la tierra e mais tarde em El hombre, alcança agora a sua culminância.

2.5.6.2. O dominado coletivo patenteia-se com vigor por intermédio de um ator individual, consciente de uma determinada hicrarquia social e econômica niveladora dos homens, à qual se submete.

2.5.6.3. Torna a configurar-se a morte do "dominador" como na Encosta das Comadres; novamente se trata de um ato premeditado, porém agora suscetível de significaçāo simbólica: um "dominado" em ato de defesa pessoal mata o dominador.

2.5.6.4. O desenvolvimento diegético destaca as injustiças que se cometem com o "dominado": trato habitual que recebe do patrāo, ausência de possibilidade de defender-se do crime que the imputam.

2.5.6.5. E reforçada a função da religiāo em relaçāo ao domínio.

2.6. Conclusões parciais

2.6.1. Macario ć, com efeito, um relato que simbolicamente prefigura a relação "dominador - dominado". Os dois primeiros termos empregados para definir esta relação: "domínio vs. acatamento", sāo válidos para todos os relatos considerados.

2.6.2. A oposição "dominador - dominado" ć plasmada nos quatro relatos considerados sob a perspectiva do dominado, a qual corresponde a funçāo de narrador homodiegético; isto contribui para uma captaçāo imediata e realizada do dominado e a uma intensilicaçāo da denúncia ideológica. No quinto relato, En la madrugada, há um narrador heterodiegético cuja visão é completada pela do narrador homodiegético, criando-se um interessante entrelaçamento de perspectivas coincidentes que ideologicamente se reforçam.

2.6.3. O grau de consciência dos "dominados" com respeito a sua situação se mostrou variável: consciência desde a inconsciência (Macario, Nos han dado la tierra) até a consciência (La cuesta de las comadres) e o reconhecimento discursivo dessa consciência (El hombre, En la madrugada).

2.6.4. Estes diferentes graus de consciência nāo suscitam nenhuma variante no desenvolvimento diegético, posto que tampouco quando o dominado é lúcido a respeito de sua situação é capaz de reagir organizadamente contra ela. La Cuesta de las comadres é o único relato em que se nota uma reação emotiva negativa suscitada pelo domínio.

2.6.5. Très classes de "dominador" foram evidenciadas (excessão feita do relato prefigurador, Macario)

2.6.5.1. Um dominador impessoal que corresponde ao sistema oficial vigente (Nos han dado la tierra, El hombre, En la madrugada) 
2.6.5.2. Um dominador pessoal, sem linhagem, que rouba terras, infunde temor é obcdccido e odiado. (La cuesta de las comadres)

2.6.5.3. Um dominador pessoal com linhagem, reverenciado como superior (En la madrugada)

2.6.6. A religião cumpriu uma função nestes três relatos: intensificaçāo da rclação de dominio em Macario e En la madrugada, configuraçāo de um correlato objetivo em virtude do qual se pōe ironicamente clara a relação de domínio em Nos han dado la tierra.

\section{Pedro Páramo}

3.1. Atualizaçāo da oposiçāo actancial Dominador $\left\{\begin{array}{l}\text { Pedro Páramo...... Miguél Páramo (latifundiá- } \\ \text { A Igreja }\end{array}\right.$

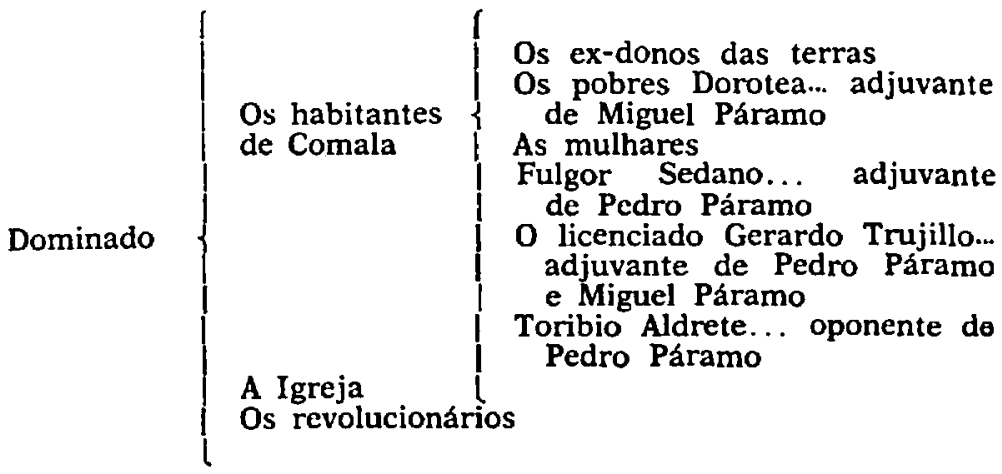

O actante "dominador" está representado na figura de Pedro Páramo. Como projeção sua, aparece no filho, Miguel Páramo.

A Igreja está representada em ambas as categorias: "dominador/dominado", pois recebe ordens de Pedro Páramo e exerce poder espiritual sobre os pobres seja no que diz respeito a sua sorte ultraterrena, seja no que diz respeito a sua desesperança na terra. O seguinte esquema, no qual as flechas mostram a ação de domínio esboçaria a situação existente:

\section{Pedro Páramo \\ Igreja $\}$ Os pobres}

Particularizamos no primeiro esquema os habitantes de Comala que, gênero ou individuo, aparecem destacados no texto. Em quatro casos, dois actantes se sincretizam num ator. Dorotea, 
Fulgor Sedano, o licenciado Gerardo Trujillo e Toribio Aldrete. 3.3. Os atores dominadores. 93

3.3.1. Pedro Páramo ${ }^{94}$

Pedro Páramo, assim como don Justo En La madrugada, ć o "paträo" e sua dignidade como tal será reconhecida. Diferentemente dos Torricos meros forastciros que no começo possuíam poucas terras como o resto dos habitantes de A Encosta das Comadres - Pedro Páramo herdou a Media Luna de seu pai dom Lucas, também o patrão. 95

Pedro Páramo recebe o tratamento respeitoso - Dom Pedro - e. quando necessário, o exige: "Mas nāo te esqueças do "dom" 96 diz a Fulgor Sedano no começo das relaçōes entre ambos.

2.3.1.1. Traços que contribuem a intensificar a figura de Pedro Páramo

3.3.1.1.1. Seu nome serve de título à obra o que já o define como figura de especial relevo $(O$ mesmo acontece $\mathrm{cm}$ Macario mas a escolha é mais representativa no romance. Tendo em vista o maior número de possibilidades). O nome Pedro Páramo é significativo: corresponde a uma primeira descrição de personagem (qualificativa e funcional), que se verifica num plano figurado: Pedro = pedra $=$ dureza, alicerce, fundamento (dureza de Pedro Páramo, Pedro Páramo alicerce de Comala); páramo = terreno árido, plano, desabrigado; qualquer lugar sumamente frio e desamparado. 97

Estas denominações prefiguram o desenvolvimento diegético: Pedro Páramo deixa de sustentar Comala (o apoio de Pedro Páramo corresponde a um dominio ativo, substituido por uma dominação passiva) e Comala se transforma em lugar deserto. 98

93 Para uma melhor compreensāo de nossa análise - devido a fndole do texto envertenos a ordem $c$ apresentamos, primeiramente, o estudo dos atores dominadcres.

94 O tema Pedro Páramo dominador já ioi planteado em diferentes artigos, sendo que alguns estabelcceram relaçōes com a realidade extra-textual mexicana. Ver: O'NEIL, p. 288 e seguintes. MIRÓ, p. 240, DORFMAN. Em tomo a Pedro Páramo de Juan Rulfo. In: GIACOMAN p. 155-158, BLANCO AGUINAGA In: SOMMERS, p. 109. HARS, Luis. Los nuestros. Buenos Aires, Sudamericana, 1966, p. 330.

95 O grifo é nosso.

96 "-Como tú quieras. Pero no se te olvide el "don" ". (p. 39.

$97 \mathrm{Diz}$ Barthes: "Um nome próprio deve ser sempre interrogado cuidadosamente, porque o nome próprio é, se se pode dizer, o príncipe dos significantes; suas conotaçōes são ricas, socials e simbólicas". BARTHES, Roland. Analyse textuelle d'un conte d'Edgar Poe. In: CHABROL, C. Sémiotique narrative et textuelle. Paris, Larcusse, 1973, p. 34 .

98 Octavio Armand em Sobre las comparaciones de Rulfo faz uma consideracāo sutil em relação aos nomes em Pedro Páramo: "Pedro Páramo, quase Pedras Pedras. é o árido, o mineral, se se quiser; o que cruza os braços com uma vontade de ferro. Fica fácil compreender porque Susana (o liquido) se sente mais apegada a Florencio (o vegetal) do que a Pedro Páramo: este necessariamente tem que se caracterizar pela falta daquela". (ARMAND, p. 343). 
3.3.1.1.2. A descrição que Abundio oferece de Pedro Páramo para identificá-lo, exalta o poder de Pedro Páramo e condensa um traço essencial de tal ator. As perguntas de Juan Preciado: - O senhor conhece Pedro Páramo? [...] "Quem é? [Abundio responde:] "- Um rancor vivo".99 Rancor que permitirá explicar a transformação de Pedro Páramo em "dominador" e a morte de Comala. A vingança de Pedro Páramo por causa da festa que, inconscientemente, se origina em Comala quando da morte de Susana San Juan, provoca a ruína do povoado: "Cruzarci os braços e Comala morrerá de fome". 100

3 3.1.1.3. Scu físico é excepcional. O texto oferece duas referências sobre o seu especial tamanho: "Ali estava ele, enorme, 101 olhando". 102 "[...] o corpo enorme de Pedro Páramo". ${ }^{103}$ Seu atrativo quando jovem é sugerido: agrada a Dolores e a Eduviges. Dolores, quando Fulgor Sedano lhe transmite a proposta de matrimônio de Pedro Páramo, responde: "- mas se ele pode escolher. Existem tantas moças bonitas em Comala. Que dirão elas quando souberem. 104

3.3.1.1.4. Aparece como "o grande macho" e dispōe das mulheres que deseja: "Me acuso padre de que ontem dormi com Pedro Páramo". "Me acuso padre de que tive um filho de Pedro Páramo". "De que cmprestei minha filha para Pedro Páramo". 105 Não é por casualidade que sejam seus filhos os dois atores primeiramente apresentados no romance: Juan Preciado e Abundio. Diz Damiana, referindo-se a Pedro Páramo: "O que não entendo é porque lhe agrada fazer as coisas tão às escondidas; se tivesse me avisado já teria dito a Margarida que o patrāo necessitava dela para esta noite e ele não teria tido nem o trabalho de levantar-se da cama". 106

2.3.1.1.5. O dominador adquire especial relevo ao ser mostrada a sua infância, o seu íntimo (amor por Susana San Juan), mediante o emprego de um método apresentativo. Sua limitação pessoal é

99 “- ?Conoce usted a Pedro Páramo? [...] - ?Quíén es? [Abundio responde] - Un rencor vivo" p. 10.0 grifo é nosso.

100 "Me cruzaré los brazos y Comala se moriré de hambre" p. 121.

1010 grifo é nosso.

102 "Alli estaba él, enorme, mirando" p. 71.

103 "... el cuerpo enorme de Pedro Páramo" p. 109 e seguintes. O grifo é nosso.

104 "- Pero si él tiene de dónde escojer. Abundan tantas muchachas bonitas en Comala. ?Qué dirán ellas cuando lo sepan?" p. 42.

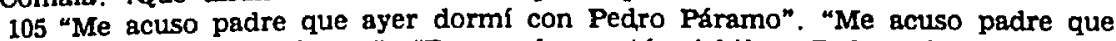
tuve un hijo de Pedro Páramo". "De que le presté mi hija a Pedro Páramo" p. 73.

106 "Lo que no entiendo es por qué le gusta hacer las cosas tan a escondidas; con habérmelo avisado, ya le hubiera dicho a Margarita que el patrón la necesitaba para esta noche, y él no hubiera tenido nl la molestia de levantarse de su cams" p. 110 . 
mencionada: nunca chegou a conhecer nem a se impor ao mundo interior de Susana San Juan. O ator adquire uma dimensão humana oposta a impersonalidade do "dominador" em Nos han dado la tierra. El hombre e a da autoridade jurídica de En la madrugada.

3.3.1.1.6. Existe em Pedro Páramo consciência de que deverá pagar por suas açōes. Quando Miguel Páramo morre, Pedro Páramo diz: "- Estou começando a pagar. Mais vale começar cedo. para terminar depressa". 107

3.3.1.1.7. Pedro Páramo adolescente, aparece possuidor de um traço peculiar no mundo esboçado: ao ser vítima de exploração não se resigna c reage diante da arbitrariedade de que é objeto. Refere a sua avó a seguinte situaçāo que ele se nega a admitir: "Rogelio quer que lhe cuide a criança. Passo o tempo passeando com ela. Mas é muito trabalho atender às duas coisas: à criança e ao telégrafo, enquanto ele vive tomando cervejas no bilhar. Além disso não me paga nada". 108 Quando a avó tenta acalmá-lo, Pedro Páramo responde: "Que se resignem outros, avó, eu não estou para resignaçōes. 109

\subsection{Provoca a admiração de Fulgor Sedano por sua audácia.}

3.3.1.1.9. Adquire categoria mítica: a exaltação de seus feitos contribui à mitificação da figura de Pedro Páramo, comprensível na atmosfera surrealista de Comala 110

Observação: a presença de todos estes traços contribuirá a expansão da figura de Pedro Páramo, ator que vai atrair atenção do leitor virtual exercendo nele um efcito sedutor. Advertimos, conseqüentemente, uma clara inversão com respeito à configuraçāo da oposição nos relatos analisados de El llano en llamas: o término da oposição potenciado em cada um deles, era o "dominado"; em Pedro Páramo adquire primazia, o "dominador". Esta inversão não pode deixar de exercer efcito na função ideológica que cumpre a oposição. Conjuntamente com outros fatores (por exem-

107 “- Estoy comenzando a pagar. Más vale empzzar temprano, para terminar pronto" p. 72.

108 "Rogelio quiere que le cuide al niño. Me paso paseándolo. Cuesta trabajo atender las dos cosas: al niño y al telégrafo, mientras que él se vive tomando cervezas en el billar. Además no me paga nada" p. 24.

109 "- Que se resignam otros, abuela, yo no estoy para resignaciones" p. 24.

110 Sobre o caráter mítico de Pedro Páramo ver SOMMERS, Joseph. Através de la ventana de la sepultura: Juan Rulfo. In: - La marrativa de Juan Rulfo. p. 157. Carlos Fuentes destacou $O$ uso sutil que Rulfo faz dos grandes mitos universais em Pedro Páramo. FUENTES, Carios. Ia nueva novela hispanoamericana. México, Mortiz, 1969, p. 16. 
plo o caráter surrealista de Pedro Páramo 111) esta inversão determina que a denúncia ideológica seja menos evidente no romance que nos contos (nāo consideramos Macario, pois nesse dito relato, a oposição se dá num plano figurado, com caráter inaugural). A crítica ideológica existe, no entanto, sutilmente plasmada, em Pedro Páramo, e sua compreensão é indispensável para a compreensão do romance.

3.3.1.2. Pedro Páramo latifundiário.

3.3.1.2.1. Abundio - no diálogo com Juan Preciado já mencionado - mostra a extensāo do latifúndio de Pedro Páramo. "Bom, pois isso é a Media Luna de ponta a ponta. Como quem diz, toda a terra que se pode abarcar com o olhar". 112

3.3.1.2.2. Pedro Páramo exalta o latifúndio como sistema natural. Diz a Fulgor Sedano: "Não te preocupem os muros. Não haverá muros. A terra não tem divisōes".113

3.3.1.3. Aquisição e consolidação de seu poder.

3.3.1.2.1. E introduzido o fator desencadeante de sua atuaçāo: "A morte de seu pai, que arrastou outras mortes". $114 \mathrm{E}$ isso que a dom Lucas apenas the tocou por acaso porque parece que a coisa era contra o noivo. E como nunca se soube de onde tinha saído a bala que o atingiu a ele, Pedro Páramo morreu parelho". 115

3.3.1.3.2. Pedro Páramo inicia sua linha ascendente como dominador, a partir de uma situaçāo econômica deteriorada (ausência de dinheiro e gado). Para consolidar sua posição recorre a determinados procedimentos, dois dos quais aparecem destacados diegéticamente:

- Contrai matrimônio com Dolores Preciado, sua credora

- Manda assassinar Toribio Aldrete.

Sua linha geral de conduta pode ser assim caracterizada:

- Apodera-se da terra dos outros

- Dispõe a seu arbítrio da vida das pessoas

- Impōe-se à lei

111 A irrealidade de Pedro Páramo foi captada por Julio Ortega e Samuel O'Neill: "Este é um mundo completamente irreal onde a irracionalidade é a forma corrente y näo se pode estar certo de nada. E o mundo dos sonhos de Kafka". Ver o artigo Pedro Páramo. In: GIACOMaN, p. 294.

112 "Bueno, pues eso es la Media Luna de punta a cabo. Como quien dice toda la tierra que se puede abarcar con la mirada" p. 10.

113 "No te preocupem los lienzos. No habrá lienzos. La tierra no tiene divisiones" p. 41.

114 "La muerte de su padre que arrastró otras muertes" p. 71.

115 "Y eso que a don Lucas nomás le tocó de rebote, porque al parecer la cosa era contra el novio. Y como nunca se supo de dónde habla salido la bala que le pegó a él, Pedro Páramo arraso parcjo" p. 83. 
- Domina por meio do dinheiro o poder espiritual encarnado na Igreja.

- Compra a revoluçāo.

Os três primeiros traços assinalados vinculam Pedro Páramo aos Torricos (La Cuesta de las Comadres).

3.3.1.4. Morte de Pedro Páramo

Pedro Páramo morre assassinado assim como os Torricos e don Justo; em nenhum dos três casos se trata de morte programada pelo dominado. A morte de Pedro Páramo, assim como a do outro patrão, don Justo, transcende a uma perspectiva simbólica: o dominado - filho, Abundio, dá morte ao dominador - pai, Pedro Páramo, quando este nega o que solicitara. Como ocorreu com Esteban. Abundio mata o dominador quando se acha privado de suas faculdades, neste caso, em estado de embriaguês. A morte do dominador em En la madrugada trará como conseqüência a morte do dominado mas a ordem imperante nāo sofrerá nenhuma modificação. A morte de Pedro Páramo corresponde ao desmoronamento definitivo de Comala, já iniciado a partir da decisão do dominador.

3.3.2. Miguel Páramo

3.3.2.1. Aparece como projeção de Pedro Páramo. Este último se identifica com seu filho, cujos atos e culpas pretende assumir: "A culpa de tudo o que ele faça joguem em mim". 116 Pode-se entender que estas culpas se anulam na invulnerabilidade de Pedro Páramo. Na realidade, para ele, as vítimas de seu filho nāo existem: ("Essa gente não existe" 117) e cle as esquece (" e se esqueceu de todo o resto" 118). Porém, por outro lado, Pedro Páramo sabe que tem que pagar ( $p$. 72). Nesse momento, como em outros, o texto nos submerge na ambiguidade. Fulgor Sedano capta a semelhança entre pai e filho, assim como certo elemento que os difcrencia e que causará a morte de Miguel: sua impetuosidade, seu ir "jogando carreira com o tempo". 119

3.3.2.2 Dispōe das mulheres e, diferente de seu pai, é mostrado como violentador. Dorotea é a mediadora (adjuvante) que lhe consegue as mulheres.

3.3.3. - A Igreja 120

116 "La culpa de todo 10 que el haga échenmela a mi" p. 8.

117 "Esa gente no existe" p. 69.

118 "Y se olvidó de todo lo demás" p. 69.

119 "Jugando carreras con el tiempo" p. 68.

120 "Os habitantes de Comala, como pessoas que possuem uma simples fé primitiva, se teriam renovado se alguma vez tivessem sido absolvidos de seu sentimento de culpa. No entanto, as figuras religiosas - o sacerdote e dois bispos recusam uma e outra vez garantir o perdão. A negação da absolviçāo religiosa gravita pesadamente na mente do povo. Eles vivem em condições de constante pecado". FREEMAN, Donald. La escatologia de Pedro Páramo. In: GIACOMAN, p. 265. 
Da Igreja depende a salvação espiritual, que é negada aos pecadores que nāo tem dinheiro. Diz o padre Rentería a Maria Dyada, a respeito do perdão de Eduviges; "- Digo que talvez, as missas gregorianas; para isto precisamos pedir ajuda, mandar trazer um sacerdote. E isso custa dinheiro. Ali estava diante de mim o olhar de Maria Dyada. uma pobre mulher cheia de filhos.

"- Não tenho dinheiro. Isto o senhor sabe. padre.

- Vamos deixar as coisas como estão a esperar cm Deus". 121

3.3.3.2. Os pecados dos pobres se acumulam como um déficit crescente e sem solução. A irmā de Donis explica a Juan Preciado:

Aqui, estas horas estão cheias de espanto. Se o senhor visse o número de almas que andam soltas pela rua. Logo que escurece começam a sair e ninguém gosta de vê-las. São tantas, e nós somos tão poucos que já nem lutamos para rezar para que deixem de penar. Nossas oraçôes nāo seriam suficientes para todos. Talvez recebcssem um pedaço de padre nossa e isso não lhes pode servir de nada. Ainda estão nossos pecados no meio. Nenhum dos que ainda vivemos aqui está na graça de Deus. Ninguém poderá alçar seus olhos ao céu sem sentí-los sujos de vergonha. 122

3.3.3.3. A fé é mantida nos crentes pela superstiçāo e pelo medo, conforme afirmação do padre de Contla, que poderia ser considerado como um ator portador da verdade, segundo a estimativa do texto (p. 75).

3.3.3.4. A Igreja demonstra sua implacabilidade com os dominados": Donis e sua irmã - tăo necessitados de "conservar geração" como as filhas de Lot 123 - mantêm relaçōes incestuosas. A moral do bispo é rigida e sem concessões: culpa e condena. 124 Refere a irmã de Donis a Juan Preciado:

121 "- Digo tal vez, si acaso con las misas gregorianas; pero para eso necesitamos pedir ayuda. mandar traer sacerdote. $Y$ esto cuesta dinero.

"Alli estaba frente a mis ojos la mirada de Maria Dyada, una pobre mujer llena de hijos.

"- No tongo dinero. Esto usted lo sabe, padre.

“- Dejemos las cosas como están. Esperemos en Dios" p. 35.

122 "Aqui esas horas están llenas de espanto. Si usted viera el gentío de ánimas que andan sueltas por la calle. En cuanto oscurece comienzan a salir y a nadie la gusta verlas. Son tantas, y nosotros tan poquitos, que ya ni la lucha le hacemos para rezar porque salgan de sus penas. No ajustarian nuestras oraciones para todos. Se acaso les tocaria un pedazo de padrenuestro y eso no les puede servir de nada. Luego están nuestros pecados de por medio. Ninguno de los que todavía vivimos está en gracia de Diós. Nadie podrá alzar sus ojos al cielo sin santirlos sucios de vergilenza" p. 55 .

123 31: "Então a maior caisš à menor: nosso pai estå velho e não há varăo sobre a terra que entre $\in m$ nós conforme o costume de toda a terra: 32 Vem. demos de beber a nosso pai e durmamos com ele e conservemos de nosso pai geração. $36 \mathbf{E}$ conceberam as duas filhas de Lot de seu pai. BfBLIA, A. T. Genesis XIX, p. 18.

$124 \mathrm{E}$ interessante relacionar csta atitude com as "condenaçōes do senhor padre" em Macario. 
E a vergonha não cura. Pelo menos foi isso o que me disse o bispo que passou por aqui há alguns tempos atrás para crismar.

Fui diante dele e contei tudo:

"- Isto não se perdoa - me disse

"- Estou com vergonha.

"- Não é o remédio.

"- O senhor nos case!

"- Separem-se!

"- Eu quis lhe dizer que a vida nos tinha juntado, prendido e posto um ao lado do outro Estávamos tāo sós aqui, que os unicos éramos nós. $E$ de alguma forma tinha que se povoar o povoado.

Talvez já tinha a quem crismar quando regresse.

"- Separem-se. Isto é tudo o que se pode fazer.

“- Mas como vamos viver?

"- Como vivem os homens.

E foi embora, montado na sua mula, o rosto duro, sem olhar para trás como se tivesse deixado ali a imagem da perdição". 125

E importante destacar a diferença entre este episódio e seu correlato bíblico: a uniāo de Lot com suas filhas não foi amaldiçoada por Deus e, pelo contrário. dcu origem a uma importante descendência: de Lot e sua filha mais velha nasce Moab. fundador do povo Moab (Biblia. A.T. Genesis, XIX, 37, f. 18) ao qual pertence Ruth, antecessora do rei David Biblia, A.T. IV, 17, p. 288.

3.3.3.5. O pagamento do clizimo que a Igreja exige, contribui ao empobrccimento do povo (p. 17).

3.2. Os atores dominados

3.2.1. Os habitantes de Comala são conscientes da onipotência de Pedro e a acatam. 126

125 “- Y la verguenza no cura. Al menos eso me dijo el obispo que pasó por aqui hace alguin tiempo dando confirmaciones.

Yo me le puse enfrente y le conté todo:

"- Eso no se perdona - me dijo.

“- Estoy avergonzada.

“- No es el remedio.

"— !Cásenos usted!

"- Apórtense!

"- Yo le quise decir que la vida nos habia juntado, acorralándonos y puesto uno junto al otro. Estábamos tan solos aqui, que los únicos éramos nosotros. Y de algún modo habia que poblar el pueblo. Tal sez tenga ya a quien confirmar cuando regrese.

"-Separense. Eso es todo lo que se puede hacer.

"- Pero? cómo viviremos?

"- Como viven los hombres.

$Y$ se fue, montado en su macho, la cara dura, sin mirar hacia atrás como si hubiera dejado aquí la imagen de la perdición" p. 55.

126 Faremos referéncia a alguns dos atores assinalados no esquema inicial. 
3.2.1.1. Os ex-donos das terras.

"- E quem diz que a terra nāo é minha?

- Afirma-se que a vendeste a Pedro Páramo.

- Não cheguei nem perto desse senhor. A terra continua minha.

- Isso dizes tu. Mas por aí dizem que tudo é dele.

- Que me venham dizer isto a $\mathrm{mim}$.

- Olha Galileo, eu a ti, aqui entre nós, eu te aprecio. Por algo és o marido de minha irmā. De que a tratas bem, ninguém duvida. Mas a mim nāo me vais negar que vendeste as terras.

- Digo-te que não as vendi a ningućm.

- Pois são de Pedro Páramo. Certamente ele assim o decidiu. Dom Fulgor não veio te ver?

- Não.

- Certamente amanhã ele virá. E se nāo for amanhã, qualquer outro dia.

- Pois me mata ou morre; mas não sairá com a sua.

- Requiscat in pace, cunhado. Pelas dúvidas". 127

\subsubsection{Dorotea}

3.2.1.2.1. Dorotca mostra com lucidez o efeito que a Igreja suscita nos "dominados": "A única coisa que faz a gente se mexer é a esperança de, ao morrer, ser levado de um lugar para outro; mas quando fecham uma porta para a gente c só fica aberta a do inferno, mais vale não ter nascido [...]" 128

3.2.1.2.2. Dorotea $\dot{e}$ talvez o ator que configura a imagem mais acabada da miséria: seu estômago é visto oniricamente como uma casca de noz: "encolhido pela fome e pelo pouco comer"; 129 a mostra de sua miséria aparece unida em um dos seus sonhos a dureza dos santos do céu, tão insensivel como os sacerdotes da terra. (p. 65).

127 "- ?Y quién dice que la tierra nos es mía?

- Se afirma que se la has vendido a Pedro Páramo.

- Yo ni me le he acercado a ese señor. La tierra sigue siendo mia.

- Eso dices tú. Pero por ahí dicen que todo es de él.

- Que me lo vengan a decir a mí.

- Mira, Galileo, yo a tí, aquf en confianza, te aprecio. Por algo eres el marido de mi hermana. Y de que la tratas bien, ni quién lo dude. Pero a $\mathrm{ml}$ no me vas a negar que vendiste las tierras.

- Te digo que a nadie se las he vendido.

- Pues son de Pedro Páramo. Seguramente él así lo ha dispuesto. ?No te ha venido a ver Don Fulgor?

- No.

- Seguramente mañana lo verá venir. Y si no mañana, cualquier otro día.

- Pues me mata o se muere; pero no se saldra con la suya.

- Requiescat in paz, amén, cuñado. Por si las dudas" p. 48.

128 "Lo único que la hace a una mover los pies es la esperanza de que al morir la lieven a una de un lugar a ot,ro; pero cuando a una le cierran una puerta y la que queda abierta es nomás la del infierno, más vale no haber nacido..." p. 70 . 129 "engarruñada por las hambres y por el poco comer" p. 64 . 


\subsubsection{O licenciado Gerardo Trujillo}

O licenciado Gerardo Trujillo, adjuvante de Lucas Páramo, de Pedro Páramo e de Miguel, intenta manter uma imagem digna cliante de Pedro Páramo, mas a nccessidade econômica se impõe e o licenciado se rebaixa:

- Dom Pedro, regressei. pois nāo estou satisfeito comigo mesmo. Continuarei tratando de seus assuntos com prazer. Disse isto sentado novamente no escritório de Pedro Páramo, onde havia estado nāo fazia nem meia hora.

- Está bem, Gerardo. Aí estão os papéis onde tu os deixastes. - Desejaria também... Os gastos... A mudança... Um mínimo adiantamento de honorários... Algo extra, se é que senhor não se incomoda.

- Quinhentos?

Nāo poderia ser um pouco, digamos um pouquinho mais? 130

\subsubsection{A Igreja}

2.2.2.1. O dinheiro compra a salvação das almas. O padre Rentería acredita que Miguel Páramo - personagem pecador contra quem mantém uma quota de ressentimento pessoal - não merece absolviçāo. Pedro Páramo dá de esmola um punhado de moedas para a Igreja (compra simbólica do perdão). O padre Rentería deixa a decisāo concernente à salvação de Miguel Páramo nas mãos de Deus. Segundo a interpretaçāo - errada ou não do sacerdote - Deus perdoa a Miguel Páramo. No segundo caso se configuraria a imagem de uma divindade também comprável. A prece de Pedro Páramo a Deus é mais profunda que as outras - segundo palavras de padre Renteria - não somente porque Pedro Páramo é o pai de Miguel. senāo e primordialmente porque é rico (p. 32).

3.2.2.2. Explicitamente, o padre Rentería - ator eminentemente conflitivo reconhece sua dependência dos ricos, sua traição aos pobres e se culpa por isto: "Tudo isto acontece é por minha culpa - disse a si mesmo. O temor de ofender aqueles que me sustentam. Porque esta é a verdade; eles me mantêm. Dos pobres não consigo nada; as oraçōes não enchem estômago". 131 A rea-

130 "- Don Pedro, he regresado, pues no estoy satisfecho conmigo mismo. Gustoso seguirá llevando sus asuntos. Lo dijo sentado nuevamente en el despacho de Pedro Páramo, donde habia estado no hacia nt mecila hora.

- Está bien, Gerardo. Alli están los papeles, donde tú los dejaste.

- Desearía también... Los gastos... El traslado... Um mínimo adelanto de honorários... Algo extra, por si usted lo tiene a bien.

- TQuinientos?

- ?No podría ser un poco, digamos un poquito más?"

131 "Todo esto que succde es por mi culpa - se dijo. Es temor de ofender a quienes me sostiencn. Porque ésta es la verdad ellos me dan mi mantenimiento. De los pobres no consigo nada; las oraciones no llenan el estómago" p. 34. 
lidade parece impor-se ineludivelmente ao padre Rentería (se não acatasse os ricos não poderia manter-se) e os pobres (nada podem obter com sua $\mathrm{f}$ (́). E esboçado assim um mundo sem possibilidades. Em um único momento, sob a influência do padre de Contala, o padre Rentería se atreve a opor-se - minimamente - a Pedro Páramo: recusa um convite dele para comer (p. 77) 132

3.2.2.3. O padre de Contla, representante da moral convencional, condena o padre Renteria: "Esse homem, de quem não queres mencionar o nome, despedaçou a tua igreja c tu consentiste. Que se pode esperar já de ti. padre? Que fizeste da força de Deus?" 133 Segundo a visão do padre de Contla, o domínio de Pedro Páramo não corresponde a uma realização da vontade de Deus.

3.2.2.4. Graças ao papel de intermediária que lhe atribui Miguel Páramo. Dorotea terá assegurado o seu sustento, mas - configurando-se outro círculo implacável, isto será causa de sua condenaçāo eterna.

3.2.3. Os revolucionários 134

3.2.3.1. Aparecem como atores fracos, manobráveis, desconhecedores dos motivos de sua ação:

- Bem. Que desejam? - tornou a perguntar Pedro Páramo.

- Como o senhor está vendo, pegamos em armas.

$-\mathrm{E}$ ?

- E pois isto é tudo. Lhe parece pouco?

- Mas porque o fizeram?

- Pois porque outros o fizeram também. Não o sabe? Espere um pouquinho até que nos cheguem instruções e entāo averiguaremos a causa. No momento já estamos aqui. 135

132 "O padre Rentería é um dos outros individuos cuja vida espiritual busca $\mathrm{B}$ independência do cac:que, mas cujas necessidades físicas requerem a ajuda do amo. Vive isolado na sua angústia pessoal, e simboliza um setor do clero latinoamericano que depende da ajuda dos ricos para sobreviver". O'NEILL, p. 291.

133 "Ese hombre de quien no quieres mencionar su nombre ha despedazado tu iglesia y tú se io has consentido. ?Qué se puede esperar ya de tí, padre? ?Que has hecho de la fuerza de Dios?" p. 75.

134 O tema da revoluçäo aparece desenvolvido no conto El llano en llamas e nele já se adverte o caráter absolutamente frustrante da revoluçāo no sentido de uma realidade melhor.

135 “- Bien ?Que se les ofrece? - volvió a preguntar Pedro Páramo.

- Como usted ve, nos hemos levantado en armas.

- ?Y?

- $\mathrm{Y}$ pos eso es todo. ?Le parece poco?

- ?Pero por qué lo han hecho?

- Pos porque otros lo han hecho también. ?No lo sabe usté? Aguárdenos tantito a que nos lleguen intrucciones $y$ entonces averiguaremos la causa. Por lo pronto ya estamos aquí" p. 101 . No dizer de Joseph Sommers "Dentro do romance, a Revolução simboliza a futilidade de toda a história e suas inelicazes consequências, assim como a sua natureza bárbara". Ver SOMMERS, p. 164. 
3.2.3.2. O padre Rentería vai para a revolução num intento - entendemos - de superar seus problemas de consciência e escapar à influência de Pedro Páramo. Ocorre, no entanto, que Pedro Páramo comprou os revolucionários e a revolução não instaura nada de novo.

3.2.3.3. A revolução poderia corresponder simbolicamente a uma transformação da ordem estabelecida; mas o texto se encarrega de desmentir esta possibilidade, sob a perspectiva dos dominados: “- Entāo não foste ver ao padre Rentería?

- Fui. Mas me informaram que andava no cerro.

- Em qual cerro?

- Pois pelos andurriais. A senhora sabe que anda na revolução.

- De maneira que ele também? Pobre de nós, Abundio.

- A nós que nos importa isso, mãe Villa? Tanto faz como tanto fez". 136

3.4. Definição e configuraçāo da relação actancial

A fórmula correspondente é (a vs. b) $+c+d$

Frente à unicidade ou à dualidade de perspectivas narrativas apontadas nos contos, nos enfrentamos com uma pluralidade de focos narrativos que contribuem para a complexidade do romance e a configuraçāo mais sutil e menos evidente da oposisição "dominador-dominado".

3.5. Função da novela em relação à oposição que nos ocupa.

3.5.1. Expansão da figura do "dominador", que adquire um relevo que não the correspondeu noutros relatos.

3.5.2. Pedro Páramo reitera a figura de dom Justo (En la madrugada), mas se configura também seu caminho ascensional, por meio do qual realiza açōes que o tornam semelhante aos Torricos (La cuesta de las comadres).

3.5.3. A visão ideológica surge:

3.5.3.1. da configuração de uma hierarquia, em virtude da qual a ação de domínio se torna mais complexa: os dominados aparecem oprimidos sob a autoridade dos dominadores: latifúndio e igreja.

3.5.3.2. do estático da realidade imperante que aparece explicitamente definida por meio da reduçāo e da ineficácia dos revolucionários, assim como da consciência dos próprios dominados a respeito de sua situaçāo que nāo pode ser transformada seja na existência terrena, seja na existência ultraterrena. na qual a salvação lhes é inacessivel.

136 "- ?Qué no fuiste a ver al padre Rentería?

- Fui. Pero me informaron que andaba on el cerro.

- ?En cual cerro?

- Pos par esos andurriales. Usted sabe que andan en la revuelta.

- ?De modo que también el? Pobres de nosotros Abundio.

- A nosotros qué nos importa eso, madre Villa. Ni nos va ni nos viene p. 124. O grifo é nosso. 
4. Conclusōes gerais

4.1 Nossa análise mostrou a presença de oposição actancial "dominador-dominado" em cada um dos textos considerados.

4.2 Mostramos que os dois termos da oposição "dominador-dominado" sāo realçados de modo inverso nos contos e no romance: maior dimensão dos dominados nos primeiros, dimensāo maior do dominador no último. A este traço corresponde uma função ideológica ostensiva nos contos à exceçāo de "Macario" - e uma função ideológica mais sutil - porém incontestável, em Pedro Páramo.

4.3 Comprovamos a prefiguraçāo simbólica da relaçāo "dominador-dominado" em Macário. Tal prefiguração đá maior vigor à crítica ideológica implícita nos outros relatos selecionados de El llano en llamas e em Pedro Páramo, textos nos quais a oposiçāo adquire literalidade.

4.40 processo total esboçado com respeito à oposição "dominador-dominado" no corpus escolhido se configura, segundo o exposto, assim:

a) Prefiguração da relação de domínio com ênfase no "dominado" ( $\mathrm{Ma}$ cario).

b) Literalização da relação de domínio, com ênfase no "dominado" (Nos han dado la tierra), La cuesta de las comadres, El hombre, En la madrugada.

c) Inversão do término relevante da oposição: realce do "dominador". (Pedro Páramo).

4.5 Captamos certas correspondências entre Pedro Páramo e os Torricos (La cuesta de las comadres) e o fato de Pedro Páramo e dom Justo (En la madrugada) pertencerem a um modelo comum (o patrão). Estas coincidências confirmam nossa visão relativa ao caráter isótopo da obra de Rulfo.

4.6 Apreciamos diferentes níveis de participação e influência da religião na oposiçāo "dominador-dominado":

a) A religiāo utilizada como instrumento de domínio (Macario, Pedro Páramo)

b) A religião como integrante de uma hierarquia de dominio, obedecendo à autoridade do senhor feudal e impondo-se aos dominados (Pedro Páramo).

c) A religião como sustentadora de um correlato brblico que pōe de manifesto a crítica ideológica (Nos han dado la tierra, Pedro Páramo).

4.7 Os textos estudados configuram um ciclo que se inicia em Macário com a figura da mãe (madrinha) e termina em Pedro Páramo, com a figura do pai (o patrão), duas manifestaçōes polares do actante dominador, possuidores de todas as ressonâncias mítico-simbólicas próprias à imagem materna e paterna. Em outro nível, os dominadores, toda uma série, individuais, coletivos, pessoais, impessoais, configuram - como mostramos nas conclusōes parciais, três ordens:

a) Dominador impessoal que corresponde ao sistema oficial vigente 
(o governo em "Nos han dado la tierra", o sistema jurídico em "El hombre" e cm "En la madrugada").

b) Dominador pessoal, desprovido de linhagem (Los Torricos em "La cuesta de las comadres").

c) Dominador pessoal provido de linhagem (dom Justo, em "En la madrugada", Pedro Páramo).

4.8. A denúncia idcológica, a captamos projetada não somente no dominador (causa eficiente da injustiça e arbitrariedade), como também no dominado (seu aniquilamento pessoal, sua infra-humanidade - já antecipada em Macario - que o impede de uma reação planificada). A única semente "organizada" de rebelião está nos revolucionários de Pedro Páramo, que aparecem, porém, como atores reduzidos, inconscientes de sua atuação, suscetíveis de ser manobrados e, ao contrário, garantia de que a ordem estabelecida nāo se modificará, nāo se transformará.

A visão de mundo que os textos entregam é sem esperança; a ordem configurada aparece como fatal e estática, a vida terrena é para os "dominados" um "vale de lágrimas" e a ultraterrena, um "vale de expiação".

A crítica idcológica em Rulfo, sutilmente sugerida nunca proclamada, ativará o leitor virtual e por meio deste o leitor real, mostrando-lhe aspectos de um mundo injusto e instando-o, por vezes, ao trânsito do texto para a realidade extra-textual. ***

\section{REFERENCIAS BIBLIOGRAFICAS}

ANALISIS, estructural del relato. Buenos Aires, Tiempo Contemporáneo, 1970. 280 p. BIBLIA. A. T. La santa Biblia; antiguo y nuevo testamento. S. 1. Sociedades Biblicas Unidas, 195i. $292 \mathrm{p}$.

CHABROL, C. Sémiotique narrative et textuelle. Paris, Larousse, 1973. 223 p. DICCIONARIO de la lengua española. Madrid Real Academia Española, 1956.

FUENTES, Carlos. La nueva novela hispanoamericana. Mexico, Mortiz, 1969. 98 p. GENETTE, G. Figures III. Paris, Seuil, 1972. $281 \mathrm{p}$.

GIACOMAN, H. F. Homenaje a Juan Rulfo. Madrid, Anaya/Las Americas, 1974. 394 p. GREMMAS, A. J. Du sens. Paris, Seuil, 1970. 313 p.

- Essais de sémiotique poétique. Paris, Larousse, 1972. 238 p.

- Semántica estructural. Madrid, Gredos, 1973. 398 p.

HARS, L. Los nuestros. Buenos Aires, Sudamericana, 1966.462 p.

PEREZ RIOJA, J. A. Diccionario de simbolos y mitos. Madrid, Tecnos, 1962.

RULFO, J. El llano en llamas, Mexico, Fondo de Cultura Económica, 1965. 143 p. . Pedro Páramo. Mexico, Fondo de Cultura Económica, 1955. 129 p.

SOMMERS J. La narrativa de Juan Rulfo; interpretsciones criticas. Mexico, SEP/Setentas, 1974, $166 \mathrm{p}$.

\section{Resumo}

O trabalho postula que as obras de Rulfo El llano en llamas e Pedro Páramo, devido as suas constantes, são configuraçōes de uma isotopia. O cobjetivo foi verificar e analisar uma dessas constantes: a oposição actancial 
"dominador-dominado" a qual atribuimos uma função ideológica. A análise realisada mostrou que os termos da oposição "dominador-dominado" são tealçados de modo inverso nos contos e no romance: maior dimensão dos dominados nos contos e maior dimensão do dominador no romance, sendo que a função ideológica aparece de forma ostensiva nos contos e mais sutilmentc em Pedro Páramo. O processo total que cumpre a oposiçāo estudada, no corpus escolhido, se mostrou configurado do seguinte modo: a) prefiguração da relação de domínio com ênfase no dominado (Macario) b) representação da relação de domínio com ênfase no dominado (Nos han dado la tierra, La cuesta de las comadres. El hombre. En la Madrugada) c) inversão do termo relevante da oposição: realce do dominador (Pedro Páramo). A denuncia icieológica - sutilmente sugerida - foi captada nāo somente no que se refere ao dominador, como no que se refere ao dominado, incapaz duma reação planificada. Plasma-se assim uma visāo do mundo sem esperanças, mas rendente a suscitar uma reação crítica no leitor virtual e através deste no leitor real.

\section{Resumen}

El trabajo postula que las obras de Rulfo, El llano en llamas y Pedro Páramo, debido a sus constantes, son configurados de uma isotopia. El objetivo ha sido verificar y analizar una de esas constantes: la oposición actancial "ojominador-dominado", a la que adjudicamos una funcion ideológica. El análisis realizado mostró que los términos de la oposición "dominador-dominado" son realzados de modo inverso en los cuentos y en la novela: mayor dimensión de los dominados en los primeros y magnificación del dominador, en la última. La función ideológica ha aparecido ostensible en los cuentos y más sutil en Pedro Páramo. El processo total que cumple la oposición estudiada, en el corpus escojido, se mostró configurado del siguiente modo: a) prefiguraciôn de la relación de dominio com énfasis en el dominado (Macario) b) literalización de la relación de dominio com énfasis en el dominado (Nos han dado la tierra, La cuesta de las comadres, El hombre, En la madrugada) c) inversión del término relevante de la oposición: realce del dominador (Pedro Páramo). La denuncia ideológica - sutilmente sugerida - la hemos captado proyectada no sólo al dominador sino también al dominado, incapaz de una reacción planificada. Se plasma asi una visión de mundo desesperanzada, pero tendiente a suscitar una reacción critica en el lector virtual y a través de éste en el lector real.

\section{Summary}

This essay postulates that Rulfo's works: El llano en llamas y Pedro Paramo are, due to its constants, configurators of an isotopy. Our objective has been to verify and analize one of these constants, the actantial opposition "dominator-dominated" to which we give an ideological function. The analysis showed that the terms of the opposition "dominator-dominated" are 
emphasized inversely in the stories and in the novel: greater emphasis of the dominated in the former and greater emphasis of the dominator in the latter. The ideological function has ostensively appeared in the stories and more subtly in Pedro Páramo. The total process of this opposition in the chosen corpus, was shown to be structured in the following way: a) Prefiguration of the relation of dominance with emphasis in the dominated ("Macario") b) Literalization of the relation of dominance with emphasis in the dominated ("Nos han dado la tierra", "La Cuesta da las Comadres", "El hombre", "En la madrugada") c) Inversion of the emphasis in the terms of the opposition: emphasis in the dominator (Pedro Páramo). The ideological denunciation - subtly suggested - has been understood to be projected not only to the dominator but also to the dominated, incapable of planning a reaction. A vision of a hopeless world is so moulded. Nevertheless it tends to suscitate a critical reaction in the virtual reader and through it in the real teader.

rt* Agradeço a Sunnifer Siminovich e a Jeanette Elazar, a colaboração prestada. 